
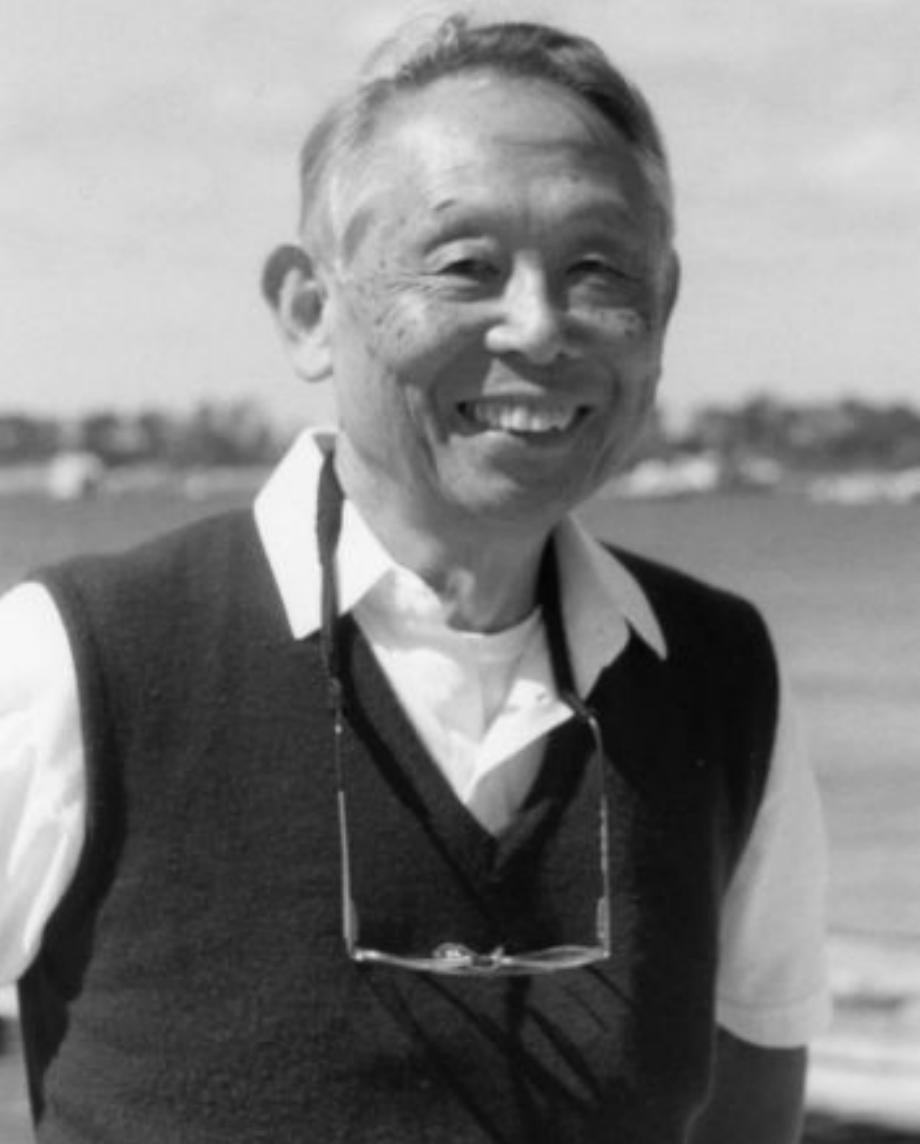


\title{
MICROTUBULE DYNAMICS IN CELL DIVISION: \\ EXPLORING LIVING CELLS WITH POLARIZED LIGHT \\ MICROSCOPY
}

\author{
Shinya Inoué \\ Marine Biological Laboratory, Woods Hole, MA 02543 \\ jmacneil@mbl.edu
}

Shortened running title: Microtubule dynamics in mitosis

Corresponding author: Shinya Inoué, Marine Biological Laboratory,

7 MBL Street, Woods Hole, MA 02543-1015, USA, T: 508-289-7382,

F: 508-540-6902, E: jmacneil@mbl.edu 


\section{INTRODUCTION}

Classically the light microscope was used to examine preserved, thin-sectioned tissues and cells. More recently it has become an important tool for exploring the molecular basis of physiological functions directly in active living cells. The major transition to its modern use was prompted by optical advances in the mid $20^{\text {th }}$ century, followed by another spurt in the 1980 's brought about by electronic imaging and striking advances in molecular biology.

While I was able to participate in both recent transitions in microscopy, this Perspective covers my experience during the earlier part of those events. By following the birefringence in dividing cells with an improved polarizing microscope, we learned about the reality of spindle fibers; the dynamic organization of their filaments; and their labile, assembly/disassembly, and force-generating properties. The dynamic behavior of molecules making up the birefringent spindle filaments could now be followed directly in actively dividing cells.

Our studies on live cells were followed by the isolation of a "colchicine-binding protein," identified as the microtubule protein, and by the discovery that microtubules could be disassembled or assembled in vitro. Those studies verified our analysis of the birefringence observed in living cells and opened up vast new avenues for exploring the molecules and mechanisms involved in mitosis and a wide range of related cellular events.

As may be apparent from my publications including this essay, I have been interested in improving the capabilities of the light microscope and exploring its uses, as much as in uncovering the submicroscopic structures and dynamic events taking place in the living cell. Today many have contributed immensely and made unbelievable advances in both of these fields (see e.g., Howard \& Hyman 2007, Maiato et al. 2004, Pawley 2006, Sluder \& Wolf 2003, 
Wittmann et al. 2001). The current essay, thus, focuses on events relating to some early developments in which I had the good fortune to contribute. ${ }^{1}$

\section{ENCOUNTER WITH KATIE AND JEAN DAN: INTRODUCTION TO LIVING CELLS}

Born 1921 in London, England as the eldest child of a Japanese diplomat, I was brought up together with my sisters in several countries. I enjoyed my early school years in Portland, Oregon, and Sydney, Australia, but from 1932 I remained in Japan to enter a municipal high school in Tokyo.

From my early days, I was interested in figuring out how to build electric motors and tiny portable radios that actually worked, but not so much in biology. My mother gave me a small microscope, but it was so disappointing; nothing in the prepared slides was doing anything. Still, at our home, I did raise silk worms and later even collected and mounted butterflies on occasion. But in high school, the only thing that really impressed me in biology was the behavior of a bird's feather that our teacher let us examine under a loupe. The tiny, barbed hooks allowed the feather to be ruffled, yet be zippered neatly back together. The image seen through a magnifier finally explained how something actually worked!

My deeper interest in biology was aroused in 1941, while I was a student at Musashi Koto Gakko, a junior college in Tokyo. There I met Professor Katsuma Dan (frivolously nicknamed Katie by himself) in the first class that he taught in his home country (Figure 1). Katie had returned to Japan in 1937 with his American wife, Jean Clark Dan, a fellow graduate student who had also worked with L. V. Heilbrunn at the University of Pennsylvania, and with whom he had spent summers at the Marine Biological Laboratory (MBL) in Woods Hole. 
As a student who had been unhappy with the high school classes in militaristic Japan, I was shocked but delighted by Katie's different attitude and approach. Instead of promoting rote learning, he told us about how he and his friends were figuring out how cells divided, by tracing the movement of kaolin particles placed on the surface of developing sea urchin eggs. And how Karl von Frisch took advantage of the sugar rationing in Germany during World War I to explore how honey bees found their way back home by using polarization of the sky light to navigate, then dancing and signaling to their hive mates how to reach the nectar source.

In the lab, Katie let his students try experiments that might or might not work, rather than have us follow pre-tested procedures. I still cannot forget the excitement of having been able to show how Lillie's iron wire model of nerve conduction worked by successive electrical depolarization (of a passivated layer on a steel wire immersed in concentrated nitric acid) rather than by propagation of a chemical change as argued by my class mates. And I found that even the conduction speed could be enhanced by making the current jump past a locally insulated segment of the model [just as Ichiji Tasaki demonstrated the same year for saltatory conduction in myelinated nerve fibers (Tasaki \& Takeuchi 1941)]!

But that was the year the Japanese Navy attacked Pearl Harbor, and Japan and the United States became embroiled in World War II. Still, unlike many of my former high school class mates, especially the A students who had become navy officers and soon perished at sea, I was deferred from military service as a science major (until four months before the end of the war when everybody was conscripted). Thus, I was able to enter Tokyo Imperial University in 1942 and finish the curtailed 2.5-year curriculum with a major in zoology.

One evening in 1943, Katie invited me to his home in Kudan, Tokyo, to try visualizing the "spindle" during cell division. Imaging the mitotic spindle in living cells was of particular 
interest to Katie; he posited that egg cells divided by an elongating spindle pushing apart the two astrospheres attached to its poles (Dan 1943). The problem was that the spindle itself was generally not visible under the microscope in living cells.

A notable exception, as Katie noted, was W. J. Schmidt's 1937 observation of developing sea urchin eggs made with a polarizing microscope (Figure 2). As re-interpreted by Schmidt himself in 1939, those pictures showed the football-shaped spindles whose contrast depended on the birefringence produced by aligned protein molecules (Schmidt 1939; see Figure 5 and associated text for explanation of birefringence).

That evening in Tokyo, Katie fertilized clear eggs of sea urchins which he had brought home from the marine lab in Misaki. Under air-raid black-out curtains, we spent several hours trying to see the spindle birefringence, using a polarizing microscope that Katie had borrowed from his colleague in Geology. But alas, the evening ended with inconclusive results.

\section{THE “SHINYA-SCOPE”}

Five years later we resumed these studies, this time at the Misaki Marine Biological Station which Katie had recovered in 1945 from the allied occupation forces using his message entitled "The last one to go" (reproduced in Article 56 in Inoué 2008). At Misaki, rather than use a commercial polarizing microscope, I started from scratch by assembling parts on a cast-off machine gun base. (The Station had been taken over by the Japanese Navy for the last year of the war as a miniature submarine base, so some destroyed weapon parts were scattered.) On the cast-iron base, I tied by string: a Zeiss microscope which Katie let me modify, a calcite polarizing prism loaned by Professor Koana of the Physics Department of Tokyo University, and an AH-4 mercury arc lamp that I found at a surplus store and which I placed in a tea can. 
Using this home-made instrument (Figure 3), we could finally repeat Schmidt's observations. For several minutes before the egg was cleaved, we saw the birefringent spindle and asters emerge and grow, then the spindle splitting into two parts as the asters grew larger. But the initial success was dashed when I tried to improve the image by rotating the objective lens to minimize the stray light introduced by strain birefringence in the lenses. The field between crossed polarizers did, in fact, become darker, but where were the birefringent spindles? They had simply vanished!

Katie's admonition to me was, "I told you to leave well enough alone." But I was really curious and wanted to make the system work better. It did take a whole month, but I finally realized that the birefringence of the strained lens was, in fact, helping by acting as a compensator and raising the image contrast of the weakly birefringent spindle. So I split a thin sheet of mica and placed it on the microscope's rotatable sub-stage filter holder so that its orientation could be adjusted, namely, so that it would act as a Brace Koehler compensator.

Now, even though the microscope field was not completely dark, we could see the brighter or darker football-shaped spindle against a gray background (Figure 4). In fact, we could see quite a bit more than in Schmidt's publication and even guess at the orientation of the component molecules.

By way of explanation, a compensator introduces uniform birefringence over the whole field of view so that, between crossed polarizers, the specimen appears brighter or darker depending on whether its birefringence is adding or subtracting from the birefringence of the compensator. As shown in Figures 4 and 5, where the "slow" axis of the specimen (e.g., the length of the spindle filaments) lies parallel to the slow axis of the compensator, the specimen appears brighter. Where the axes are crossed (lie in opposite quadrants) they appear darker, or 
are "compensated." [Every birefringent (= doubly refractive) material has two refractive indexes which reflect the arrangement of their molecular lattice or fine structure. The direction for which (the electrical vector of) the light wave suffers the greatest refraction is called the slow axis, and the one with the lowest refraction is called the fast axis. For further explanations, see e.g., Bennett 1950; Appendix III in Inoué 1986; Inoué 2002.]

In the paper reporting these observations (Inoué \& Dan 1951), I also calculated the optimum amount of compensation required to maximize the image contrast of weakly birefringent objects in the presence of stray background light (as also published nearly concurrently by Swann \& Mitchison in 1950).

The microscope I built in Misaki, and sketched from memory in Figure 3, was used extensively by Kayo Okazaki and Katie to follow the development of biocrystalline skeletal spicules in sea urchin embryos (Okazaki \& Inoué 1976). After my departure to Princeton in 1948, Kayo and Katie called it the "Shinya-Scope."

In 1948, Jean Dan returned to Misaki from her first post-World-War-II trip back home to the United States. She was full of news about their friends in the States, especially at the Marine Biological Laboratory (MBL) in Woods Hole, Massachusetts. And she brought home, as a present for her husband Katie, a Bausch and Lomb phase contrast microscope (the first one available in the United States and acquired courtesy of the American Philosophical Society). Jean, who soon discovered the acrosomal reaction, used this microscope extensively to study sperm-egg interactions at fertilization. For me, she arranged a financial loan from her sister Peggy Chittick of Milford, Connecticut, so that I could travel and study in the States.

TO PRINCETON (1948-51) 
In the fall of 1948, with a post-war Japanese passport (which I recall was number 50), I arrived at Princeton's Biology Department. There, while building what I hoped was a better polarizing microscope, I was introduced to classical cytology by my mentor, Kenneth W. Cooper. Ken had studied with Franz Schrader, who in turn had followed E. B. Wilson's steps, all three at Columbia University in New York. It was, therefore, natural for me to wonder how chromosomes moved in mitosis and about the enigmatic properties of the mitotic spindle.

At Princeton I was exposed to Wilson's classical volume on the hereditary role of chromosomes and the structure and function of the mitotic spindle in cell division (Wilson 1928). Summarizing four-decades-long studies on fixed and stained cells made by many cytologists, he describes the fibrillar structure of the "achromatic" spindle and astral rays. Still he is puzzled about the ephemeral nature and invisibility of the spindle fibrils in living cells and questions the validity of the "contractile fibrillar hypothesis" for chromosome movement favored by many. At the same time, he is reluctant to accept "that the fibrillae seen in sections may not really pre-exist approximately as such in the living cell" and cautions us not to "prematurely condemn a theory which may yet be re-concilable with the so-called dynamical theories" (Chapter II, Section IV on The Mechanism of Mitosis in Wilson 1928).

The more physico-chemically oriented proponents of the "dynamical theory" experimented with living cells and tended to be skeptical of the existence of the fibrous elements of the spindle and asters. They considered them to be artifacts of fixation.

In a 1929 article, Karl Bělař compared behavior of live grasshopper spermatocytes with carefully fixed and stained cells (Figure 6). Although unable to see any spindle structure in healthy live cells, he observed Brownian motion preferentially along the direction of fibrils which would appear after fixation. Also, from the distortion of live cells treated with hyper- 
osmotic media, he concluded that spindle fibrils or some longitudinal lamellar material must exist in the living cell despite their invisibility.

By observing chromosome movement in dividing stamen hair cells of Tradescantia, Bungo Wada proposed that spindle fibers were not made up of coherent filaments but of short thin rods as in a liquid crystal (Wada 1950). Similarly, observing the migration of chromosomes which appeared to cut right through kinetochore fibers, Gunnar Östergren also favored the liquid crystalline nature of spindle "fibers" (Östergren 1949).

These and other views in the early 1950's on the physical nature of the mitotic spindle, as well as various proposals on how chromosomes move in mitosis, are summarized in Franz Schrader's monograph Mitosis: The Movement of Chromosomes in Cell Division (Schrader 1953). In this volume, he points out two cases in which spindle fibers were actually observed in intact dividing cells. They were made by L. R. Cleveland (1938) in Barbulanympha, a symbiotic protozoan in the wood-eating cockroach Cryptocercus, and by Kenneth Cooper (1941) in the eggs of a grass mite Pediculopsis graminum. Still, Schrader points out that these were exceptional cases and could not be taken to represent cells undergoing mitosis generally. Thus,

\section{the reality of spindle fibers and their nature remained major unresolved issues.}

While I was at Princeton, we also saw fascinating movies of dividing grasshopper spermatocytes, filmed by Kurt Michelle of Karl Zeiss using their phase contrast microscope. Subsequently, Kyojiro Shimakura captured higher resolution images of similar live cells (Figure 7), and Andrew and Wishia Bajer $(1951,1956)$ made many films of dividing endosperm cells of the African blood lily Haemanthus katherinae (Figure 8; see Supplemental Movie 1 in the online version of this article or at http://www.annualreviews.org/). In these dividing cells, the phase contrast microscope displayed the movement and shape change of chromosomes most strikingly. 
The phase contrast microscope accentuates the image contrast of those bodies whose refractive indexes are somewhat greater or less than their surroundings. In contrast to the chromosomes themselves, the spindle fibers that were supposed to move the chromosomes, and the fibrils laying down the cell plate in plant cells, were not visible in phase contrast.

In these early post-World-War-II years, the electron microscope also started to reveal many important cellular fine structures (see Perspective by Sabatini 2005). But little could be seen of the fine structure in the spindle until glutaraldehyde fixation was introduced two decades later (Sabatini et al. 1963).

Thus, the challenge for me in the late 1940's was to develop a polarizing microscope that had enough sensitivity, coupled with high enough image resolution, to show what, in fact, was going on inside dividing, living cells.

\section{THE PRINCETON MICROSCOPE}

At Princeton, I decided to start from scratch again so that I could improve on the microscope that I built at Misaki. By then I was more aware of the standard use of polarizing (or "petrographic") microscopes to study crystals and to identify minerals and ores (e.g., Hartshorne

\& Stuart 1960, Rinne \& Bereck 1953, Wahlstrom 1960, Wright 1911). These microscopes were also used by biologists to study mineralized tissue, animal skeletal muscle, plant cellulose walls, etc., which were all highly birefringent (Ambronn-Frey 1926, Bennett 1950, Frey-Wyssling 1953, Schmidt 1924, etc.). W. J. Schmidt also explored an extensive array of cellular components and cell products, many with much weaker birefringence as summarized in his second monograph (Schmidt 1937). The commercially available polarizing microscopes were, however, not 
optimally designed for observing or measuring the intricately organized, and very weakly birefringent, minute organelles in living cells.

It turned out that there was an inherent incompatibility between achieving high sensitivity for detecting weak birefringence and for gaining image resolution high enough to study structural details inside a living cell. At low condenser and objective lens numerical apertures (NAs), one could achieve high extinction and gain great sensitivity, but then the resolution was limited. Selecting objective and condenser lenses with exceptionally low strain birefringence, and polarizers and analyzers providing very high extinction, was not enough. The critical factor turned out to be the very fact that microscope lenses had to refract light to form an image. And the greater the angle of refraction, as occurs in high numerical aperture lenses, the greater the loss of extinction and, therefore, of sensitivity to detect weak birefringence.

I had examined this paradox in detail at Princeton (Inoué 1952c) but had no basic solution, so I went ahead and built my second polarizing microscope using the best arrangement and components that were made available to me at that time (including strain-free objectives selected from several hundred by Bausch \& Lomb Optical Co., a much brighter AH-6 watercooled high-pressure mercury arc lamp, a Leitz photo stand, etc.). The resulting microscope is illustrated in Figure 9.

With this microscope, I found that I could indeed gain moderately high resolution (if not at the oil-immersion level yet) of weakly birefringent structures inside living cells. Being aware that birefringence reflects the arrangement of fine structure and molecules far smaller than the resolution limit of the light microscope, and that the observations could be made without staining or otherwise interfering with the activity of the living cells, I was excited to see what I could explore with this new instrument. 


\section{FINALLY TO WOODS HOLE: REALITY AND BEHAVIOR OF SPINDLE FIBERS}

\section{AND FIBRILS}

In early summer of 1949, I finally arrived at the Marine Biological Laboratory (MBL) in Woods Hole, together with my classmates Woody Hastings and Dave Stadler, and with my new microscope in the trunk of Dave's family car.

In Woods Hole, I met many of the Dan's and Cooper's old friends about whom I had heard so much. I became acquainted with them at the mess hall where we all shared tables, in the lecture room in the shingle-covered "Old Main," in the labs, at Captain Kidd, and at Stony Beach.

These new acquaintances--Don Costello, Albert Tyler, Dan Mazia, and the Osterhoudts-introduced me to several local marine invertebrates and showed me how to collect their freshly spawned gametes. The eggs from a few species were clear enough to see the birefringent spindle and asters directly, but many were filled with yolk and other birefringent granules and too opaque to see their internal structures. I solved this problem by using an air turbine centrifuge, developed earlier by E. Newton Harvey and Bill Loomis at Princeton. Eggs layered on a cushion of isopycnotic sucrose-seawater solution could be stratified so that the spindle and asters would display their birefringence within a clear, yolk-free zone. Despite the stratification and even egg fragmentation, the spindle-containing egg fragments would continue to divide when fertilized.

By using centrifuged oocytes from the annelid parchment worm Chaetopterus

pergamentaceous, I was able to clearly see the structure of their metaphase-arrested, first meiosis spindle. This material was ideal for viewing details of spindle structure and for experimenting 
on the spindle. It stayed in metaphase without proceeding to anaphase for over an hour unless the cell was activated, for example, by fertilization or osmotic shock.

To my delight, the image resolution of the new microscope was high enough so that I could now see that the Chaetopterus oocyte spindle was not just a birefringent foot-ball-shaped structure (as seen by Schmidt 1937, Swann \& Mitchison 1950, and Katie and myself in Misaki). Instead, it was made up of birefringent fibers whose birefringence was stronger where they converged and attached to the kinetochore on each of the nine chromosomes on the metaphase plate, and at the two spindle poles. Furthermore, each of the "chromosomal, or kinetochore fibers," as well as the material of the astral rays, appeared to be made up of very thin, submicroscopic fibrils (Figure 10; Inoué 1953).

In the activated oocytes, the birefringence of the chromosomal fibers briefly rose as the cell entered anaphase, as it would also in a metaphase cell whose spindle was stretched (Figure 11). As the chromosomes were led by the chromosomal fibers to the spindle poles, the fiber birefringence dropped, except where it remained high adjacent to the kinetochore on chromosomes.

Also, as chromosomes moved polewards during anaphase, the diameter of each fiber did not increase as the fiber shortened. So I argued that, despite W. J Schmidt's claim, the loss of birefringence of the spindle material during anaphase could not be explained by a folding of its polypeptide chains (Inoué 1951b, reproduced as Article 12 in Inoué 2008).

From these observations I concluded that, while invisible in living cells with conventional microscopy, spindle fibers did really exist in living cells and were not artifacts of fixation as had been argued for half a century (Schrader 1953). Furthermore, the fibers were made up of a bundle of submicroscopic fibrils as depicted in the better preserved fixed 
specimen recorded by early cytologists. But the skeptics who had not seen the dynamic images through my microscope had yet to be convinced.

\section{CONVINCING THE SKEPTICS: SPINDLE FIBERS IN TIME-LAPSE MOVIE OF}

\section{DIVIDING CELLS}

During the school year at Princeton, I continued to improve my microscope so that I could measure birefringence in minute objects (Inoué 1951c) and also make time-lapse movies of the weakly birefringent spindle in dividing plant cells.

Among the time-lapse movies showing changing birefringence of the spindle coupled with movement of chromosomes, the most informative came from cells in the anthers of an Easter lily Lilium longiflorum. When I visited Dr. Ralph Ericson at the University of Pennsylvania, he told me that pollen mother cells in 22.4-mm-long flower buds undergo meiosis and gave me a few plants which were at just the right stage (for how the flower bud is measured, see Inoué \& Oldenbourg 1998).

Before collecting cells from the lily anthers, I found that I had to centrifuge the flower bud in a clinical centrifuge to displace the highly birefringent cell inclusions, which otherwise prevented observing the live spindle. Also, culture media for lily pollen mother cells were not known, so I diluted frog Ringer to 7/8 (a concentration where the cells would not plasmolize). Fortunately, the pollen mother cells, starting with nuclear membrane breakdown, would complete their two successive divisions despite the intense monochromatic green illumination required for many hours to record the full sequence on $16-\mathrm{mm}$ film.

At MBL, I first publicly showed the movie of the dividing Lilium pollen mother cells in the Lillie Auditorium (I believe it was in 1951). I still remember how Homer Smith, MBL's 
General Manager, light-proofed the room by personally climbing up and covering the auditorium's green house roof with a black sheet of cloth so that I (a mere graduate student) could show the film!

The movie showed the chromosomes being brought to the metaphase plate and then led polewards by the birefringent spindle fibers. Finally, birefringent fibrils re-emerged between the daughter nuclei to form the phragmoplast, and vesicles assembled in its mid-zone to form the cell plate (Figure 12; see Supplemental Movie 2 in the online version of this article or at http://www.annualreviews.org/; Inoué 1964; Inoué \& Oldenbourg 1998).

The response to this showing was most gratifying. There was no doubt that spindle fibers and the fibrils making up the fibers (made visible with sensitive polarizing microscopy) were clearly present in the living, dividing cell. Bundles of the birefringent fibrils brought the chromosomes to the metaphase plate, and shortening fibers led them to the spindle poles. After the interzonal fibers diminished, new birefringent fibrils appeared between the daughter nuclei to generate the phragmoplast. In the mid plane of the phragmoplast, the cell plate was assembled.

The question asked by Dr. Ethyl Brown Harvey, "Were those cells alive?", reflected the long-held view by many that spindle fibers and their fibrils were not present in living cells but were artifacts of fixation. But these cells were happy enough to go through their two sequential divisions! The reality of spindle fibers in living cells could no longer be doubted.

\section{LABILE NATURE OF SPINDLE FIBERS: REVERSIBLE DEPOLYMERIZATION}

\section{AND ASSOCIATED CHROMOSOME MOVEMENTS}

But what was most exciting for me was that the birefringence of the spindle fibers was

not static. It not only fluctuated and changed during mitosis but disappeared reversibly when a 
cell was exposed to low temperature (Figure 13; see Supplemental Movie 3 in the online version of this article or at http://www.annualreviews.org/; Inoué 1952b, 1964) or to the anti-mitotic drug colchicine (Figure 14; Inoué 1952a). In other words, the fibrils making up the spindle fibers would depolymerize in cold or when exposed to colchicine, only to re-polymerize when the condition was reversed.

The results with colchicine were especially intriguing. When metaphase-arrested Chaetopterus oocytes were exposed to colchicine, the spindle birefringence would gradually disappear as the fibrils depolymerized (with the kinetochore fibers being the longest to persist), but, in addition, the depolymerizing filaments actually led the chromosomes and inner spindle pole to the cell surface where the outer meiotic spindle pole was attached (Figure 14). Thus, the colchicine experiments suggested that depolymerizing filaments might generate forces adequate to pull chromosomes and the spindle poles together (Inoué 1952a).

Jumping forward to the 1970's, Ted Salmon and I showed that chromosome movement, associated with gradual loss of spindle fiber birefringence, could also be induced in metaphasearrested Chaetopterus oocytes when we dropped the temperature to an intermediate value (Figure 15; Inoué 1975). Furthermore, using a novel pressure chamber, Salmon showed that birefringence loss and chromosome movement could not only be induced by elevating hydrostatic pressure, but both became faster (up to 300 Atmospheres) as more pressure was applied (Figures 15, 16; Salmon 1975a, 1976; Salmon \& Ellis 1975). Thus, it became increasingly likely that microtubules in vivo could generate pulling and pushing forces by their assembly and disassembly. Salmon further showed that purified microtubules assembled in vitro would also depolymerize under high hydrostatic pressure (Salmon 1975b). 
In plant cells, also, the fibrils of the spindle and phragmoplast were just as labile as in animal cells. They would depolymerize when exposed to cold or treated with colchicine or even low concentrations of calcium ion as was soon to be discovered.

\section{ORIENTING CENTERS AND UV MICROBEAM EXPERIMENTS}

By the late 1950's, we developed the polarization rectifier and, thus, were able to achieve full resolution with a polarizing microscope, even using high NA oil-immersion lenses, without losing the sensitivity needed to detect weak birefringence (Inoué \& Hyde 1957).

Using this new capability, Andrew and Wishia Bajer and I followed the behavior of birefringent fibers and fibrils during mitosis in live endosperm cells of the African blood lily Haemanthus katherinae. The endosperm cell lacks a rigid cell wall, so could be flattened on an osmotically equilibrated agar sheet by gently drawing off the excess endosperm fluid. Using serial photographs and a time-lapse movie taken with rectified optics, we found positively birefringent fibrils which were aligned in the "clear zone" and "polar cap" outside of the intact nuclear envelope before the envelope started to breakdown (Figure 17; Inoué \& Bajer 1961).

As soon as chromosomes condensed further and the nuclear envelope started to break down, birefringent fibrils grew into the nucleus and attached to kinetochores to form birefringent "chromosomal fibers." Some fibrils bundled into sheaths around chromosomes.

From metaphase through anaphase, fiber birefringence converged and remained strong at kinetochore as we already saw in lily pollen mother cells and in animal cells (Figure 18; Inoué \& Bajer 1961). In telophase, more birefringent fibrils appeared parallel to the spindle's remaining "interpolar fibers" and formed the phragmoplast, as also seen in Easter lily pollen mother cells. Small vesicles accumulated in the midzone of the phragmoplast, then fused to form the cell plate. 
When the cell plate started to appear, the birefringence of the phragmoplast fibrils was strongest by the cell plate, suggesting that it (as with the kinetochores) had taken over the role of keeping the fibrils oriented. Thus, the young cell plate and kinetochores both appeared to be acting as orienting centers (Inoué \& Sato 1967).

Activities of orienting centers were further indicated by microbeam experiments. Using carefully dose-controlled UV microbeam irradiation, we could reduce or abolish the birefringence of spindle fibers or phragmoplast filaments locally in the irradiated region. When a metaphase endosperm cell of Haemanthus (with its typical plant-type spindle) was irradiated, the spindle fiber lost its birefringence not only in the irradiated area but also towards the spindle pole. Nevertheless, the birefringence persisted between the irradiated area and kinetochore (Figure 19). In telophase, the birefringent phragmoplast fibrils disappeared from the irradiated area and polewards but, again, persisted between the cell plate and irradiated area.

But whether in metaphase or with a phragmoplast, the birefringent fibrils immediately started to grow back through the irradiated area and polewards as soon as UV irradiation was stopped. Thus, spindle fiber molecules clearly grow away from the kinetochore and from the cell plate.

Microbeam experiments with animal cells were further revealing. Using crane fly spermatocytes, Forer found that birefringence was lost from the area irradiated with a UV microbeam. But in these cells, birefringent fibers persisted not only between the irradiated area and the kinetochores but also between the irradiated area and the spindle pole! In other words the irradiated area appeared as an area of reduced birefringence (Figure 20).

Furthermore, after irradiation, the area of reduced birefringence traveled polewards at a steady pace and disappeared at the spindle pole. Thus, the birefringent material not only grew 
polewards away from the kinetochore into the irradiated area but also shortened towards the spindle pole.

These observations implied a tread milling of the spindle fiber molecules from the kinetochore to the pole. (Interestingly, the spindle fibers in grasshopper spermatocytes exposed to UV microbeam show a different, more complex behavior as reported by Gerry Gordon in 1979).

Based on the dynamic distribution of spindle birefringence observed in several animal and plant cells and UV microbeam experiments, we postulated that three mechanisms align the molecular filaments which make up spindle fibers, phragmoplast fibrils, and astral rays. They are: a) activity of orienting centers, b) spontaneous alignment by concentrated formation of filaments, and c) parallel alignment to previously formed filaments. Furthermore, the orienting centers (which are now called microtubule orienting centers or MTOCs) become active one after another with progression of mitosis (Inoué \& Sato 1967).

\section{SPINDLE BIREFRINGENCE, MICROTUBE DYNAMICS, AND FORCE GENERATION FOR CHROMOSOME MOVEMENT}

In a symposium volume published in 1964, I provided photographs of birefringent spindle fiber and fibrils in a large variety of animal and plant cells undergoing normal mitosis as well as treated with cold or exposed to UV microbeam irradiation. The fibers and their oriented fibrils, which I proposed were capable of producing pulling and pushing forces by removal or addition of material, appeared to be in a labile dynamic equilibrium with their subunits (Inoué 1964). 
In our summary paper in 1967, Hidemi Sato and I showed that $50 \%$ heavy water doubles the birefringence and size of spindles and asters, signaling the reversible incorporation of subunit protein from a pool. The reversible assembly took place in under two minutes and did not require synthesis of new proteins. Thus, coupled with our earlier observations on the reversible disassembly and force-generating effects by cold and by colchicine, we postulated the presence of a dynamic equilibrium between spindle fibers [filaments] and a cytoplasmic pool of their protein subunits, and that shifts in the equilibrium were responsible for spindle assembly and also for chromosome movement (Figure 21; Inoué \& Sato 1967; see also Inoué \& Salmon 1995, Maiato et al. 2004).

In the meanwhile, Bruce Nicklas and co-workers carried out extensive micromanipulation studies on live grasshopper spermatocytes. By displacing a single chromosome with a microneedle, they demonstrated how the kinetochores are quite stably, but not irreversibly, linked by fibers to the spindle poles. Also, they showed how tension exerted on kinetochores by spindle fibers governed the position and arrangement of chromosome arms and even the coordinated onset of anaphase (Nicklas \& Koch 1969; Nicklas \& Staehly 1967, Nicklas et al. 2001).

In 1974, using rectified optics, Sato and Izutsu captured spectacular images of dynamic, birefringent spindle fibers in dividing spermatocytes of a grasshopper Chrysocraon japonicas (Figure 22; see Supplemental Movie 4 in the online version of this article or at http://www.annualreviews.org/). While the incredible activity (northern lights flickering) seen in the film could not be fully explained in 1974 (since so little was yet known of interactions between motor proteins and microtubules), the activity was interpreted as reflecting the tread 
milling of microtubules which were stochastically assembling and disassembling in dynamic equilibrium with their subunit molecules.

While our earlier physiological studies on dividing cells and the interpretation of the underlying submicroscopic events received considerable attention, at the writing of our 1967 review, the nature of the protein molecules which made up the microtubules was still in dispute. Furthermore, no one had known that microtubules could be isolated nor disassembled into subunits by cold treatment and that the chilled supernatant would reassemble into microtubules upon warming. As described below, those essential discoveries of the in vitro properties of microtubules were made by Ed Taylor and his associates shortly after Taylor himself managed to label the spindle protein using $\mathrm{H}^{3}$-colchicine (Taylor 1965).

\section{EARLY BIOCHEMISTRY}

In 1952 Dan Mazia and Katsuma Dan, using synchronously dividing sea urchin eggs, managed to isolate the "mitotic apparatus" in large quantities (Mazia \& Dan 1952). The apparatus, which included the spindle, asters, and chromosomes, was isolated by stabilizing (in cold, ethanol-treated eggs) the presumed protein gel structure by converting its - SH groups to SS with $\mathrm{H}_{2} \mathrm{O}_{2}$. The remaining cytoplasm and cell membrane were then solubilized with the detergent Duponol. While the exact identity of the proteins that make up the fibrous elements of the spindle was yet to be discovered, the early work of Mazia and Dan showed that the mitotic apparatus could, in fact, be isolated as an integral physical body. This property was also used to display the configuration of the asymmetric asters, e. g., in unequally dividing cells.

In 1965, Taylor prepared $\mathrm{H}^{3}$-colchicine with high-specific activity, which bound

reversibly to a subset of cellular sites. He also showed that in cells exposed to concentrations of 
colchicine as low as $2 \times 10^{-7} \mathrm{M}$, mitosis was blocked and metaphase figures accumulated without affecting DNA, RNA, or protein synthesis. From the data, he reasoned that if a critical fraction ( 3 to $5 \%$ ) of the cellular sites that can bind colchicine is complexed, the cell is unable to form a functional spindle (Taylor 1965).

In 1967, Ed Taylor and his student Gary Borisy found that $\mathrm{H}^{3}$-colchicine bound a $6 \mathrm{~S}$ protein found in extracts from a variety of tissues and organelles. The amount of binding correlated with the presence of microtubules but not with the number of cells that were dividing. Thus, they suggested that the colchicine-binding $6 \mathrm{~S}$ protein is a subunit of microtubules (Borisy \& Taylor 1967).

In 1972, Richard Weisenberg reported the successful repolymerization of isolated microtubule protein and showed that a very low concentration of $\mathrm{Ca}^{++}$(much lower than that released from vesicles in living cells) was sufficient to depolymerize microtubules and block their polymerization. He showed that the $2^{\circ} \mathrm{C}$ supernatant obtained from an extract of rat brain would generate microtubules when warmed to $35^{\circ} \mathrm{C}$ in the presence of $\mathrm{Mg}^{++}$-ATP (or -GTP), a $\mathrm{Ca}^{++}$-chelator (EGTA), and an organic buffer (MES, pH 6.5). Very few microtubules formed when the supernatant was incubated with $0.1 \mathrm{mM}$ colchicine (Weisenberg 1972).

The ability to reversibly depolymerize microtubules in vitro led both to the purification of tubulin, the dimeric subunit protein of microtubules, and to extensive studies of the biochemistry and assembly properties of microtubules. These included the discovery of microtubule dynamic instability which depends on hydrolysis of GTP within tubulin subunits after they polymerize into an end of a microtubule (Mitchison \& Kirschner 1984).

\section{EARLY EM}


The existence of a vast array of microtubules in all tissues was revealed after Sabatini's discovery that glutaraldehyde fixation can preserve cytoplasmic microtubules (Sabatini et al. 1963). In a symposium article published in 1966, Keith Porter summarizes evidence for the presence of a ca.-250- $\AA$-diameter, straight, ubiquitous filamentous cell component, which is particularly labile and sensitive to fixation by osmium tetroxide alone but not to glutaraldehyde followed by osmium tetroxide. In negative-stained samples, they exhibited a ca.-80- $\AA$ pitch tilted ca. $10^{\circ}$ to long axis and apparently possessing a low-density axial component. They were thought to be tubular and were named microtubules (Porter 1966).

Porter goes on to say that the microtubules primarily appear to govern cell shape and form the structural frame work of the mitotic spindle, etc., namely, to act as a "cytoskeleton." He also notes that their presence is apparently required for transport of cell inclusions and organelles, and for cytoplasmic streaming, since the distribution and orientation of microtubules in the cell correlate with these functions. "But the force-generating role, if any, and the mechanism of force generation by microtubules are unclear."

Others, in the meantime, had observed "tubular cytoplasmic filaments" with the electron microscope (Harris 1962, Robbins \& Gonatas 1964, Roth 1967). In the axopodia of a Heliozoan, Tilney et al. demonstrated, both by electron microscopy and polarization optics, the reversible loss of microtubules exposed to cold or hydrostatic pressure and later to colchicine (Tilney et al. 1966, Tilney \& Porter 1967), just as we had seen in the birefringent mitotic spindle filaments in dividing cells.

In 1975, using metaphase spindles isolated from a star fish oocyte (with a fixative that precisely preserved their birefringence), we were able to establish that the birefringence of the spindle fibers in living cells exactly measured the distribution and concentration of their 
microtubules. Thus, we finally gained proof that, so long as the spindle is fixed in such a way that its birefringence is precisely preserved, the (form) birefringence of the spindle fiber measures the number of microtubules per square micrometer in EM cross section (Figure 23; Sato et al. 1975).

\section{CONCLUDING REMARKS AND UPDATE}

In this Perspective, I reminisced on our early studies with polarized light microscopy to explore the detailed structure and dynamic properties of the mitotic (and meiotic) spindles directly in living cells. These studies proved that spindle fibers and fibrils were, indeed, present in healthy living cells even though previously they could mostly be seen only after fixation and staining.

Our polarization optical studies on active living cells also confirmed the highly labile nature of the spindle fibers and their fibrils and the fact that they were dynamically organized by orienting centers such as kinetochores, spindle poles, or the cell plate. These findings, which had been surmised by classical cytologists, could now be followed within individual living cells with high time resolution and unambiguously within individual living cells. Thus, the behavior of spindle fibrils followed with polarized light microscopy foretold the reversible assembling, dynamic properties of isolated microtubules which had not yet been discovered.

In addition, by observing the action of colchicine on the spindle structure in living cells, I suggested that chromosome movement could be induced by depolymerization of spindle fibrils (Inoué 1952a).

While met with some skepticism, and despite the discovery of microtubule sliding activities powered by the motor protein, dynein, by Summer \& Gibbons (1971) and later, kinesin, 
by Vale et al. (1985), what appeared to be a somewhat counter-intuitive explanation of force generation by de-polymerizing microtubules was finally demonstrated in vitro by Koshland et al. (1988), and verified through further experiments by Coue et al. (1991). The latter authors observed the traction of a chromosome by a single depolymerizing microtubule in a cell-free system in the absence of energy-yielding nucleotides.

Today force generation by motor proteins and by assembly/disassembly of microtubules are both considered necessary for chromosome movement (Inoué \& Salmon 1995, Mitchison \& Salmon 2001, Mogilner et al. 2006).

By 1967, our accumulated data suggested that long slender fibrils, oriented by organizing centers such as the kinetochore on the chromosomes and the spindle poles, were in a labile, dynamic equilibrium with its globular subunit protein molecules, which primarily polymerized at the kinetochores and depolymerized at the spindle poles (Inoué \& Sato 1967).

While these early suggestions are consistent with modern views on the assembly and force-generating properties of mitotic microtubules (Koshland et al. 1988, McIntosh et al. 1969), in the early days I was unaware that a microtubule assembles and disassembles almost exclusively at its ends as demonstrated by Margolis \& Wilson (1978), nor that microtubules had an intrinsic polarity with their two ends having different assembly properties (Heidemann \& McIntosh 1981, Telzer \& Haimo 1981).

Thus, on the one hand, in my 1953 report I interpreted the submicroscopic structure of the spindle fibers (based on its birefringence in live Chaetopterus oocytes) as being made up of a population of long, uninterrupted thin fibrils connecting the chromosomes and spindle pole (Figure 10, lower left panel). Yet, in the schematic Figures 3 and 56 of my 1964 article, I represent the spindle fibers as being made up of short rods to stress the highly labile nature and 
the equilibrium of fibers with their pool of subunits (Inoue 1964, reproduced as Article 22 in Inoué 2008). This second representation almost suggests that I viewed the fibers to be tactoids, a possibility which I argued against in the concluding chapter of my doctorate thesis (Inoué 1951b, reproduced as Article 12 in Inoué 2008).

The contradiction is now mainly resolved by Mitchison \& Kirschner's discovery that mitotic microtubules are undergoing dynamic instability (1984). In other words, spindle fibers are made up of microtubules which individually grow long by assembly and then very rapidly shorten by disassembly. So long as that happens stochastically, each spindle fiber is made up of microtubules of varying lengths, and collectively, they are turning over rapidly in exchange with their pool of subunit tubulin molecules (Mitchison \& Salmon 2001; Waterman-Storer \& Salmon 1998).

While providing a general conceptual framework concerning force generation by assembly-disassembly of microtubules based on the dynamic equilibrium between polymer filaments and their subunits, my earlier reports neither envisioned the dynamic instability of mitotic microtubules (Mitchison \& Kirschner 1984), microtubule assembly affected by specific enzymes (Howard \& Hyman 2007), nor the exceptionally complex and dynamic molecular events that are taking place between microtubules and "motor proteins," especially at the kinetochore (e.g. Inoué \& Salmon 1995, Maiato et al. 2004, Wittmann et al. 2001).

Nevertheless, our own studies on mitotic mechanisms and microscopy development have had the good fortune to play discernible historic roles. In retrospect, we were in a fortunate position to bridge the extensive knowledge accumulated by the classical cytologists, based primarily on diligent and broad-ranging studies of fixed and stained tissues and cells (Schrader 1953, Wilson 1928), and modern cell biology which emphasizes studies based on physiology and 
molecular biology in living cells. I hope that we do not forget the rich diversity of mitotic patterns unearthed by earlier cytologists. Some will certainly shed unexpected insights into cellular organization and molecular mechanisms essential for mitosis (see Supplemental Comment 1 in the online version of this article or at http://www.annualreviews.org/).

Concerning the light microscope, well-corrected lenses were made and Zernicke's theory of microscope image formation had been fully formulated by the mid-1900's. Thus, the time was ripe for further innovations in microscopy which contributed to our ability to study active living cells over time, rather than only after fixation.

More recently, fluorescence microscopy with its several well-recognized advantages has flourished. Yet, I believe polarization microscopy has further important roles to play. Not only can we image and measure birefringence-reflecting ordered fine structure non-destructively, but also polarized light microscopy reveals inherent anisotropic interactions that take place between bond electrons and the polarized electro-magnetic light waves (see e.g., Appendix III in Inoué 1986). Thus, using advanced polarization optics, we have the opportunity to precisely locate, orient, and follow changes in selected molecules or interactions taking place between molecules. Such studies should provide further insight into the intricate organizational mechanisms and the interacting signals that are exchanged in and between cells, which are essential for continuation of cellular life and for orderly development of organisms (see Supplemental Comment 2 in the online version of this article or at http://www.annualreviews.org/).

\section{ACKNOWLEDGEMENTS}

I wish to thank Editor Randy Schekman for urging me to write this Perspective, Ted Salmon of the University of North Carolina for his many valuable inputs, Jane MacNeil and 
Grant Harris of MBL for extensive help in preparing this manuscript and movies, and authors and publishers for allowing us to reproduce previously published figures. I also thank my many friends and supporters, in and out of MBL, who made my life-long pursuits possible. These exciting adventures would not have been possible without continued and understanding support from my family, especially my wife, Sylvia.

\section{FOOTNOTE 1}

This Perspective emphasizes our early studies on the mitotic spindle and microtubules but does not cover other topics that my colleagues and I have explored using polarized light and other advance modes of microscopy. Articles reporting on a number of such biological studies and our contributions to advances in microscopy are assembled in Collected Works of Shinya Inoué: Living Cells, Light Microscopy and Molecular Dynamics just published by World Scientific Press (Inoué 2008). The volume also includes a DVD disk featuring many ciné- and video-micrographs of active living cells, and narrated explanations on polarized light microscopy. 


\section{LITERATURE CITED}

Ambronn H, Frey A. 1926. Das Polarisationsmikroskop: Seine Anwendung in der Kolloidforschung und in der Färberei. Leipzig: Akademische Verlag

Bajer A. 1951. Ciné-micrographic studies on mitosis in endosperm. III. The origin of the mitotic spindle. Exp. Cell Res. 13:493-502

Bajer A, Bajer JM. 1956. Ciné-micrographic studies on mitosis in endosperm. II. Chromosome, cytoplasmic and Brownian movements. Chromosoma 7:558-607

Bĕlař K. 1929. Beitäge zur Kausalanalyse der Mitose. II. Untersuchungen an den Spermatocyten von Chorthippus (Stenobothrus) lineatus Panz. Roux’ Archiv f. Entwmk. 118:359-484 and Plates I-VIII

Bennett HS. 1950. The microscopical investigation of biological tissues with polarized light. In Handbook of Biological Technique, ed. CE McLung, pp. 591-677. New York: Harper \& Row

Borisy GG, Taylor EW. 1967. The mechanism of action of colchicine: binding of colchicine- ${ }^{3} \mathrm{H}$ to cellular protein. J. Cell Biol. 34:525-33

Bragg WL, Pippard AB. 1953. The form birefringence of macromolecules. Acta Crystallogr. Sect. B. Struct. Crystallogr. Chryst. Chem. 6: 865-67 
Cleveland LR. 1938. Origin and development of the achromatic figure. Biol. Bull. 74:41-55

Cooper KW. 1941. Visibility of the primary spindle fibers and the course of mitosis in the living blastomeres of the mite, Pediculopsis granimum Reut. Proc. Natl. Acad. Sci. U.S.A. $27: 480-83$

Coue M, Lombillo VA, McIntosh JR. 1991. Microtubule depolymerization promotes particle and chromosome movement in vitro. J. Cell Biol. 112(6):1165-75

Dan K. 1943. Behavior of the cell surface during cleavage. VI. On the mechanism of cell division. J. Fac. Sci. Tokyo Imp. Univ. (Ser IV) 6:323-68

Forer A. 1965. Local reduction in spindle birefringence in living Nephrotoma suturalis (Loew) spermatocytes induced by ultraviolet microbeam irradiation. J. Cell Biol. 25:95-117

Frey-Wyssling A. 1953. Submicroscopic Morphology of Protoplasm. Amsterdam: Elsevier Gordon G. 1979. Unexpected increase in poleward velocities of mitotic chromosomes after UV irradiation of their kinetochore fibers. J. Cell Biol. 83:376a (see Article 32 in Inoué 2008 for additional note)

Harris P. 1962. Some structural and functional aspects of the mitotic apparatus in sea urchin embryos. J. Cell Biol. 14:475-85 
Hartshorne NH, Stuart A. 1960. Crystals and the Polarising Microscope: A Handbook for Chemists and Others. London: Arnold, $3^{\text {rd }}$ ed.

Heidemann SR, McIntosh JR. 1981. Visualization of the structural polarity of microtubules. Nature 286:517-19

Howard J, Hyman AA. 2007. Microtubule polymerases and depolymerases. Curr. Opin. Cell Biol. 19:31-35

Inoué S. 1951a. Doctoral Thesis Part I. Introduction. Published as Article 7 in Collected Works of Shinya Inoué: Microscopes, Living Cells, and Dynamic Molecules. 2008. Singapore: World Scientific Publishing

Inoué S. 1951b. Doctoral Thesis Part VI. The submicroscopic structure of the spindle in living cells. Published as Article 12 in Collected Works of Shinya Inoué: Microscopes, Living Cells, and Dynamic Molecules. 2008. Singapore: World Scientific Publishing

Inoué S. 1951c. A method for measuring small retardations of structures in living cells. Exp. Cell Res. 2:513-17

Inoué S. 1952a. The effect of colchicine on the microscopic and submicroscopic structure of the mitotic spindle. Exp. Cell Res. Suppl. 2:305-18 
Inoué S. 1952b. Effect of temperature on the birefringence of the mitotic spindle. Biol. Bull. $103: 316$

Inoué S. 1952c. Studies on depolarization of light at microscope lens surfaces. I. The origin of stray light by rotation at the lens surfaces. Exp. Cell Res. 3 (1):199-208

Inoué S. 1953. Polarization optical studies of the mitotic spindle. I. The demonstration of spindle fibers in living cells. Chromosoma 5:487-500

Inoué S. 1964. Organization and function of the mitotic spindle. In Primitive Motile Systems in Cell Biology, ed. RD Allen, N Kamiya, pp. 549-98. New York: Academic Press

Inoué S. 1975. Dynamics of mitotic spindle organization and function. In Molecules and Cell Movement, ed. S. Inoué, RE Stephens, pp. 3-30. New York: Raven Press

Inoué S. 1981. Cell division and the mitotic spindle. J. Cell Biol. 91 (3):s131-47

Inoué S. 1986. Video Microscopy. New York: Plenum Press

Inoué S. 1994. A tribute to Katsuma Dan. Biol. Bull. 1876:127-78

Inoué S. 2002. Polarization microscopy. Curr. Protoc. Cell Biol. Suppl. 13:4.9.1-27 
Inoué S. 2008. Collected Works of Shinya Inoué: Microscopes, Living Cells, and Dynamic Molecules. Singapore: World Scientific Publishing

Inoué S, Bajer A. 1961. Birefringence in endosperm mitosis. Chromosoma 12:48-63

Inoué S, Dan K. 1951. Birefringence of the dividing cell. J. Morphol. 89:423-56

Inoué S, Hyde WL. 1957. Studies on depolarization of light at microscope lens surfaces. II. The simultaneous realization of high resolution and high sensitivity with the polarizing microscope. J. Biophys. Biochem. Cytol. 3:831-38

Inoué S, Inoué TD. 1986. Computer-aided stereoscopic video reconstruction and serial display from high-resolution light-microscope optical sections. In Recent Advances in Electron and Light Optical Imaging in Biology and Medicine, ed. A Somlyo. Ann. N.Y. Acad. Sci. 483:392404

Inoué S, Oldenbourg R. 1998. Microtubule dynamics in mitotic spindle displayed by polarized light microscopy. Mol. Biol. Cell 9:1603-7

Inoué S, Salmon ED. 1995. Force generation by assembly/disassembly in mitosis and related movements. Mol. Biol. Cell 6:1619-40 
Inoué S, Sato H. 1967. Cell motility by labile association of molecules. J. Gen. Physiol. $50: 259-92$

Koshland DE, Mitchison TJ, Kirschner M. 1988. Polewards chromosome movement driven by microtubule depolymerization in vitro. Nature 331:499-504

Maiato H, DeLuca J, Salmon ED, Earnshaw WC. 2004. The dynamic kinetochore-microtubule interface. J. Cell Sci. 117:5461-77

Margolis RL, Wilson L. 1978. Opposite end assembly and disassembly of microtubules at steady state in vitro. Cell 13:1-8

Mazia D, Dan K. 1952. The isolation and biochemical characterization of the mitotic apparatus of the dividing cell. Proc. Natl. Acad. Sci. U.S.A. 38:826-38

McIntosh JR, Hepler PK, van Wie DG. 1969. Model for mitosis. Nature 224:659-63

Mitchison JM, Kirschner M. 1984. Dynamic instability of microtubule growth. Nature 312 (5991):237-42

Mitchison TJ, Salmon ED. 2001. Mitosis: a history of cell division. Nat. Cell Biol. 3:E17-21 
Mogilner A, Wollman R, Civelekoglu-Scholey G, Scholey J. 2006. Modeling mitosis. Trends Cell Biol. 16(2):88-96

Nicklas RB, Koch CA. 1969. Chromosome micromanipulation III. Spindle fiber tension and the reorientation of mal-oriented chromosomes. J. Cell Biol. 43:40-50

Nicklas RB, Staehly CA. 1967. Chromosome micromanipulation I. The mechanics of chromosome attachment to the spindle. Chromosoma 21:1-16

Nicklas RB, Waters JC, Salmon ED, Ward SC. 2001. Checkpoint signals in grasshopper meiosis are sensitive to microtubule attachment, but tension is still essential. J. Cell Sci. $114: 4173-83$

Okazaki K, Inoué S. 1976. Crystal property of the larval sea urchin spicule. Dev. Growth Differ. 18:413-34

Östergren G. 1949. Luzula and the mechanism of chromosome movements. Hereditas 35:44568

Pawley JB, ed. 2006. Handbook of Biological Confocal Microscopy. New York: Plenum Press, $3^{\text {rd }}$ ed. 
Porter KR. 1966. Cytoplasmic microtubules and their function. In Ciba Foundation Symposium on Principles of Biomolecular Organization, ed. GEW Wolstenholme, M O’Connor, pp. 308-45. London: Churchill

Rinne FWB, Bereck M. 1953. Anleitung zu optischen Unterzuchungen mit dem Polarizationsmikroskop. Stuttgart: Schweizerbart

Robbins E, Gonatas NK. 1964. The ultrastructure of a mammalian cell during the mitotic cycle. J. Cell Biol. 21:429-63

Roth LE. 1967. Electron Microscopy of Mitosis in Amebae III. Cold and Urea Treatments: A Basis for Tests of Direct Effects of Mitotic Inhibitors on Microtubule Formation. J. Cell Biol. $34: 47-59$

Sabatini DD. 2005. In awe of subcellular complexity: 50 years of trespassing boundaries within the cell. Annu. Rev. Cell Dev. Biol. 21:1-33

Sabatini DD, Bensch K, Barrnett RJ. 1963. Cytochemistry and electron microscopy. The preservation of cellular ultrastructure and enzymatic activity by aldehyde fixation. J. Cell Biol. $17: 19-58$

Salmon ED. 1975a. Spindle microtubules: Thermodynamics of in vivo assembly and role in chromosome movement. Ann. N.Y. Acad. Sci. 253:383-406 
Salmon ED. 1975b. Pressure-induced depolymerization of brain microtubules in vitro. Science 189:884-86

Salmon ED. 1976. Pressure-induced depolymerization of spindle microtubules. IV. In Production and regulation of chromosome movement. Cold Spring Harbor Conferences on Cell Proliferation, ed. R Goldman, T Pollard, J Rosenbaum, 3:1329-42. New York: Cold Spring Harbor Press

Salmon ED, Ellis GW. 1975. A new miniature hydrostatic pressure chamber for microscopy: Strain-free optical glass windows facilitate phase contrast and polarized light microscopy of living cells. Optional fixture permits simultaneous control of pressure and temperature. J. Cell Biol. 65:587-602

Sato H, Ellis GW, Inoué S. 1975. Microtubular origin of mitotic spindle form birefringence. $J$. Cell Biol. 67:501-17

Schmidt WJ. 1924. Die Bausteine des Tierkörpers in polarisiertem Lichte. Bonn: Cohen Schmidt WJ. 1937. Die Doppelbrechung von Karyoplasma, Zytoplasma und Metaplasma. Protoplasma Monographien, Vol. 11. Berlin: Gebrüder Bornträger 
Schmidt WJ. 1939. Doppelbrechung der Kernspindel und Zugfasertheorie der

Chromosomenbewegung. Chromosoma 1:253-64

Schrader F. 1953. Mitosis: The Movement of Chromosomes in Cell Division. New York: Columbia University Press

Sluder G, Wolf DE, eds. 2003. Digital Microscopy: A Second Edition of Video Microscopy. Methods in Cell Biology, Vol. 72. San Diego: Academic Press

Summer KE, Gibbons IR. 1971. Adenosine triphosphate-induced sliding of tubules in trypsintreated flagella of sea-urchin sperm. Proc. Natl. Acad. Sci. U.S.A. 68:3092-96

Swann MM, Mitchison JM. 1950. Refinements in polarized light microscopy. J. Exp. Biol. 27:226-37

Tasaki I, Takeuchi T. 1941. Der am Ranvierschen Knoten entstenhende Aktionsstrom und seine Bedeutung für die Erregengsleitung. Pflügers Arch. Physiol. 244:696-711

Taylor EW. 1965. The mechanism of colchicine inhibition of mitosis. I- Kinetics of inhibition and the binding of $\mathrm{H}^{3}$-colchicine. J. Cell Biol. 25:145-60

Telzer BR, Haimo LT. 1981. Decoration of spindle microtubules with dynein: evidence for uniform polarity. J. Cell Biol. 89:373-78 
Tilney LG, Hiramoto Y, Marsland D. 1966. Studies of microtubules in Heliozoa. III. A pressure analysis on the role of these structures on the formation and maintenance of the axopodia of Actinosphaerium nucleofilum (Barrett). J. Cell Biol. 29:77-95

Tilney LG, Porter KR. 1967. Studies of microtubules in Heliozoa. II. The effect of low temperature on these structures on the formation and maintenance of the axopodia. J. Cell Biol. $34: 327-43$

Vale RD, Reese TS, Sheetz MP. 1985. Identification of a novel force-generating protein, kinesin, involved in microtubule-based motility. Cell 42:39-50

Wada B. 1950. The mechanism of mitosis based on studies of the submicroscopic structure and of the living state of the Tradescantia cell. Cytologia 16:1-26

Wahlstrom FE. 1960. Optical Crystallography. New York: Wiley, $3^{\text {rd }}$ ed.

Waterman-Storer CM, Salmon ED. 1998. How microtubules get fluorescent speckles. Biophys. J. 75 2059-69

Weisenberg RC. 1972. Microtubule formation in vitro in solutions containing low calcium ion concentrations. Science 177:1104-5

Wilson EB. 1928. The Cell in Development and Heredity. New York: MacMillan, $3^{\text {rd }}$ ed. 
Wittmann T, Hyman T, Desai A. 2001. The spindle: a dynamic assembly of microtubules and motors. Nat. Cell Biol. 3:E28-34

Wright FE. 1911. The Methods of Petrographic-Microscopic Research: Their Relative Accuracy and Range of Application. Washington: Carnegie Institution 


\section{ARTICLE TABLE OF CONTENTS}

Introduction

Encounter with Katie and Jean Dan: Introduction to Living Cells

The "Shinya-Scope"

To Princeton (1948-51)

The Princeton Microscope

Finally to Woods Hole: Reality and Behavior of Spindle Fibers and Fibrils

Convincing the Skeptics: Spindle Fibers in Time-lapse Movie of Dividing Cells

Labile Nature of Spindle Fibers: Reversible Depolymerization and Associated Chromosome Movements

Orienting Centers and UV Microbeam Experiments

Spindle Birefringence, Microtubule Dynamics, and Force Generation for Chromosome Movement

Early Biochemistry

Early EM

Concluding Remarks and Update

Acknowledgements

Footnote 1

Literature Cited 


\section{KEY WORDS}

Mitosis, spindle fibers, dynamic equilibrium, colchicine, chromosome movement, birefringence 


\begin{abstract}
This Perspective is an account of my early experience while I studied the dynamic organization and behavior of the mitotic spindle and its submicroscopic filaments using polarized light microscopy. The birefringence of spindle filaments in normally dividing plant and animal cells, and those treated by various agents, revealed: A) the reality of spindle fibers and fibrils in healthy living cells; B) the labile, dynamic nature of the molecular filaments making up the spindle fibers; C) the mode of fibrogenesis and action of orienting centers; and D) forcegenerating properties based on the disassembly and assembly of the fibrils. These studies, which were carried out directly on living cells using improved polarizing microscopes, in fact, predicted the reversible assembly properties of isolated microtubules.
\end{abstract}




\section{FIGURE LEGENDS}

Figure 1. Katsuma Dan (1905-1996) at the Centennial Celebration of Misaki Marine Biological Station in 1987 (Inoué 1994).

Figure 2. Left: W. J. Schmidt's 1937 monograph. Right: In this monograph, on p.89, Fig. 31, Schmidt shows live, developing sea urchin eggs observed with a polarizing microscope. At the time of this publication, Schmidt interpreted the football-shaped white and dark birefringent structures as being chromosomes, rather than mitotic spindles (Schmidt 1937).

Figure 3. The author's hand-made polarizing microscope, built from salvaged components at the Misaki Biological Station in 1948 (Inoué 2008).

Figure 4. (a, b) Two-cell-stage jelly fish (Spirocodon sp.) egg with metaphase spindles observed with microscope shown in Figure 3. In these live, optically clear cells, the positively birefringent spindle appears bright or dark depending on its orientation relative to the compensator (see Figure 5 for explanation). The cell surface, which is negatively birefringent, appears in opposite contrast where it lies parallel to the spindle. Unlike in many other genera, eggs of jelly fish do not produce a fertilization envelope. (c, d, e) Fertilized, developing eggs of a sand dollar Clypeaster japonica. The Clypeaster eggs (which are exceptionally transparent) are surrounded by a fertilization envelope, which shows a strong, tangentially positive birefringence. The spindle and asters also show a positive birefringence along their long axes. Double headed arrows: slow axis direction of compensator (Inoué and Dan, 1951).

Figure 5. Micromere formation during $4^{\text {th }}$ division in developing egg of a sand dollar Echinarachnius parma (images taken with a rectified polarizing microscope in the 1970's).

The spindles in these four cells have converged to the egg's vegetal pole (the four animal pole cells are out of focus). Where the spindle long axis (orientation of microtubules) lies parallel to the compensator slow axis (SS'), the positively birefringent spindle appears bright. Where they are crossed, the spindle appears dark. (b) Cleavage planes bisect the spindle remnants and give rise to four micromeres (predecessor of spicules and gonads) and four macromeres. In the diagram below the photographs, PP' and AA' show transmission axes of polarizer and analyzer 
(which are crossed), SS' and FF' are orientation of slow and fast axes of compensator (Inoué 1981).

Figure 6. Spermatocytes of a grasshopper Chorthippus lineatus at different stages of meiosis-I. Drawings by Bělař of 6- $\mu \mathrm{m}$ sections of cells fixed in Flemming-Meves solution, stained with Iron-Hematoxilin. mi: mitochondria. x: sex chromosome. H: heteromorph tetrad (Bělař 1929).

Figure 7. Phase contrast image of a live spermatocyte in a grass hopper Chloealtis genicularibus at full metaphase. Photograph courtesy of Dr. Kyojiro Shimakura of Hokkaido University (Inoué 1964).

Figure 8. Phase contrast images of an endosperm cell of Haemanthus katherinae from (a) nuclear envelope break down, (b) metaphase, (c) late anaphase, through (d) cell plate formation (Inoué \& Oldenbourg 1998). See Movie 1 in Supplemental Material link in the online version of this article or at http://www.annualreviews.org/).

Figure 9. Shinya's Princeton microscope with schematic of optical path (Inoué 1951a).

Figure 10. $(\mathrm{a}, \mathrm{b})$ Birefringence of metaphase-arrested meiosis-I spindle in live, centrifugally clarified Chaetopterus oocyte; scale bar $10 \mu \mathrm{m}$. Lower left: Distribution of fibrils deduced from birefringence (Inoué 1953). (c) Polar view of metaphase plate seen in DIC (Inoué \& Inoué 1986).

Figure 11. Left: Birefringence of moderately stretched, live Chaetopterus oocyte spindle. Scale bar $10 \mu \mathrm{m}$ (Inoué 1953). Right: Graph of spindle fiber birefringence versus length. Spindles were stretched by gentle compression of oocyte fragment generated by centrifugation (Inoué $1952 a)$.

Figure 12. Birefringence of spindle fibers in pollen mother cell of an Easter lily Lilium longiflorum. This movie finally convinced skeptics that spindle fibers (and their dynamic submicroscopic fibrils) were actually present in living cells and were not artifact of fixation, as argued for half a century. (a) Anaphase onset. (b) Mid anaphase. (c) Phragmoplast formation. 
(d) Cell plate formation (Inoué 1964). See Movie 2 in the Supplemental Material link in the online version of this article or at http://www.annualreviews.org/.

Figure 13. Reversible loss of spindle birefringence by cold treatment of developing sea urchin egg. In these still frames copied from Movie 3, the $1^{\text {st }}$ cleavage spindle is: (a) developing, (b) has disappeared by cold treatment, (c) recovered and has reached full metaphase, (d) at cleavage onset. After chilling and returning to room temperature, the $2^{\text {nd }}$ cleavage spindle is: (e) in metaphase, (f) chilled again in anaphase. The same egg was chilled seven times; development was delayed by the duration of chilling but not arrested (Inoué 2008). See Movie 3 in the Supplemental Material link in the online version of this article or at http://www.annualreviews.org/.

Figure 14. Shortening and loss of birefringence by metaphase-arrested Chaetopterus spindle exposed to colchicine in seawater. Time in minutes and seconds after application of $5 \times 10^{-4}$ Molar colchicine (upper row) and $5 \times 10^{-3}$ Molar colchicine (lower row) (Inoué 1952a).

Figure 15. Chromosome movement induced by cooling and by elevated hydrostatic pressure in metaphase-arrested Chaetopterus oocyte. Row 1: temperature dropped from 23.5 to $5.2^{\circ} \mathrm{C}$ at time $0.0 \mathrm{~min}$. (-2.5 min frame in polarized light, other frames in DIC.) Chromosomes move to cell surface as spindle filaments depolymerize and shorten. Row 2 : temperature raised to $24^{\circ} \mathrm{C}$ at $0.0 \mathrm{~min}$. (5.8 \& $16.5 \mathrm{~min}$ frames in polarized light, others in DIC.) Chromosomes move away from cell surface as spindle birefringence and length increase. Scale bar $10 \mu \mathrm{m}$ (Inoué 1975). Row 3: 200 Atm (Atmosphere) of hydrostatic pressure applied at time $0.0 \mathrm{~min}$. (-3.0 min frame in polarized light; other frames in phase contrast; print magnification differs from Row 4.) Chromosomes move to cell surface as spindle filaments depolymerize and shorten. Row 4: pressure reduced to $1 \mathrm{Atm}$ at time $0.0 \mathrm{~min}$. $(1.25,2.25$, \& $26.0 \mathrm{~min}$ frames in polarized light; other frames in phase contrast.) Chromosomes move away from cell surface as spindle birefringence and length increase. Scale bar $10 \mu \mathrm{m}$ (Salmon 1975a).

Figure 16. (Left) Water-jacketed hydrostatic pressure chamber on Leitz polarizing microscope (Salmon \& Ellis 1975). (Right) Speed of chromosome movement and birefringence decay 
versus applied pressure. Both speeds increase as hydrostatic pressure is raised. But above 300 Atm, chromosomes no longer move as spindle microtubules disassemble too rapidly (Salmon 1976).

Figure 17. Endosperm cell of African blood lily Haemanthus katherinae preparing to enter mitosis. Left column: A few hours before nuclear envelope break down, birefringent fibrils appear in the "clear zone" outside of the envelope. Right column: As nuclear envelope starts to break down, additional fibrils from the "polar cap" grow into the nucleus. Shortly they connect to chromosomes and form the spindle. Compensator slow axis is NW-SE in panels a \& c, NESW in panels b \& d (Inoué \& Bajer 1961).

Figure 18. Mitosis and cell division in endosperm cell of the African blood lily. Birefringence of chromosomal fibers in: (a) metaphase and (b) anaphase show clearly in this flattened cell. Likewise, birefringent fibrils are clear in: (c) telophase, $(d, e)$ phragmoplast stage, and (e, f) cell plate formation (Inoué \& Bajer 1961).

Figure 19. Microbeam irradiation and recovery of metaphase spindle fibers in an endosperm cell of Haemanthus katherinae. (a) Ten seconds before one second UV irradiation. (b) Image of UV micro-mirror and supporting screw. (c) Two seconds after irradiation, fiber birefringence has disappeared from irradiated area and distally. (d) Ten seconds after irradiation, the spindle fibers have grown back through the irradiated area (Inoué, 1964).

Figure 20. Poleward migration of area of reduced birefringence induced by UV microbeam irradiation. Late metaphase spindle fibers in the spermatocyte of a crane fly Nephrotoma suturalis were irradiated at time $0.0 \mathrm{~min}$ (in bright area seen in frame $-0.5 \mathrm{~min}$ ). Where irradiated, a discrete area of reduced birefringence $(\mathrm{arb})$ appeared, then migrated to the upper spindle pole and disappeared. Anaphase started 6 min after irradiation. Scale bar $20 \mu \mathrm{m}$ (Forer 1965, Inoué 1981).

Figure 21. Schematic showing reversible movement of chromosomes and inner spindle pole to the cell surface by agents which depolymerize birefringent spindle fibers (Inoué \& Salmon 1995). 
Figure 22. Spermatocyte of a grasshopper Pardalophra apiculata observed with rectified optics shows prominent birefringent chromosomal spindle fibers. (a, b) Metaphase of meiosis-I, (c) early anaphase, (d) late anaphase. (a, c, d in additive compensation; b in subtractive compensation.) Kinetochores indicated by k, and spindle poles by p (Inoué \& Oldenbourg 1998; images courtesy of Bruce Nicklas of Duke Univ.). Movies of another grasshopper Chrysochraon japonicas (also captured with rectified optics) show prominent "Northern lights flickering" of spindle fiber birefringence which reflect the highly dynamic nature of spindle microtubules. To view these scenes, which were provided courtesy of Hidemi Sato and Kohsaku Izutsu in 1974, see Movie 4 in the Supplemental Material link in the online version of this article or at http://www.annualreviews.org/.

Figure 23. Form birefringence of meiotic spindle isolated from oocytes of a star fish Pisaster ochraceus. (a) Mass isolation of metaphase-arrested spindles using 12\% hexylene glycol. Black brackets in inset show spindle region where birefringence was measured. (b) At immersion media refractive index of 1.35 , birefringence of the isolated spindles (fixed with $3 \%$ glutaraldehyde-12\% hexylene glycol at $\mathrm{pH} 6.3$ ) remains as in life (double vertical bar to left). Perfused with carefully selected refractive index media, the measured birefringence $(*)$ exactly follows Wiener's form birefringence curve (generated using Bragg and Pippard's 1953 formula) for parallel rodlets whose refractive index is 1.52 and which occupies $2 \%$ volume. This volume fraction is identical to the fractional area occupied by the cross section of microtubules seen in electron micrograph (c) $(1-\mu \mathrm{m}$ grid at bottom). (c) The EM section was cut half way across the brackets in panel (a) inset. (d) Electron micrograph through polar region of spindle [white bar in panel (a) inset] (Sato et al 1975). 


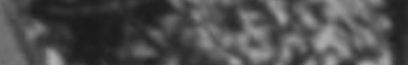

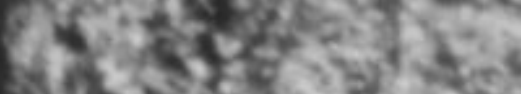

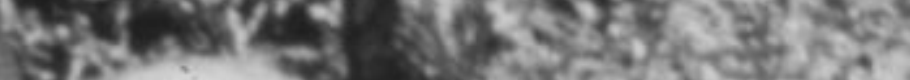

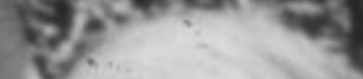

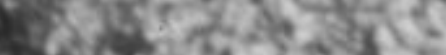

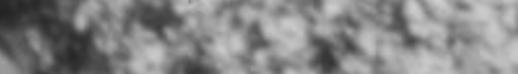

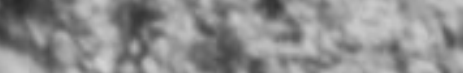

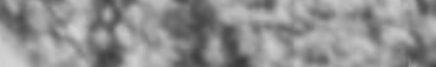

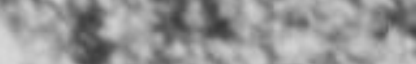
(a) was

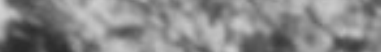

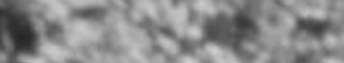

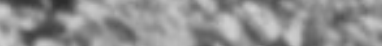

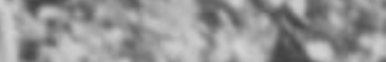

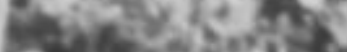

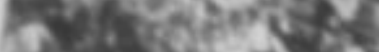
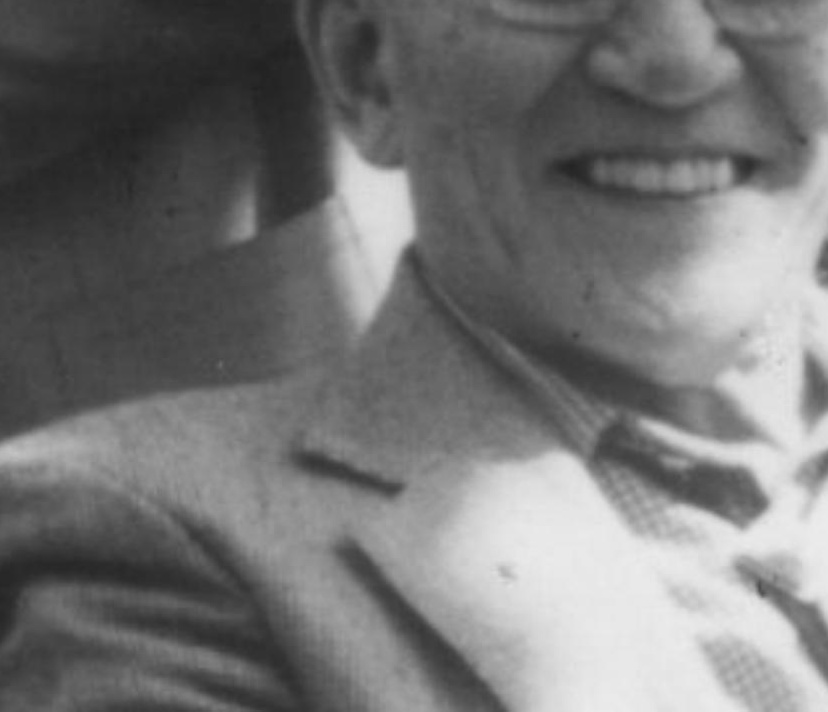

1

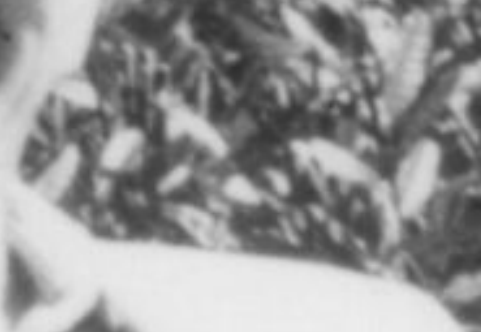

$=$ 
PROTOPLASMA MONOGRAPHIEN EIFTER BAND

DIE DOPPELBRECHUNG VON KARYOPLASMA, ZYTOPLASSMA UND METAPLASMA VaN

W.J.schmior

Gobroder Borntraeger Borlin
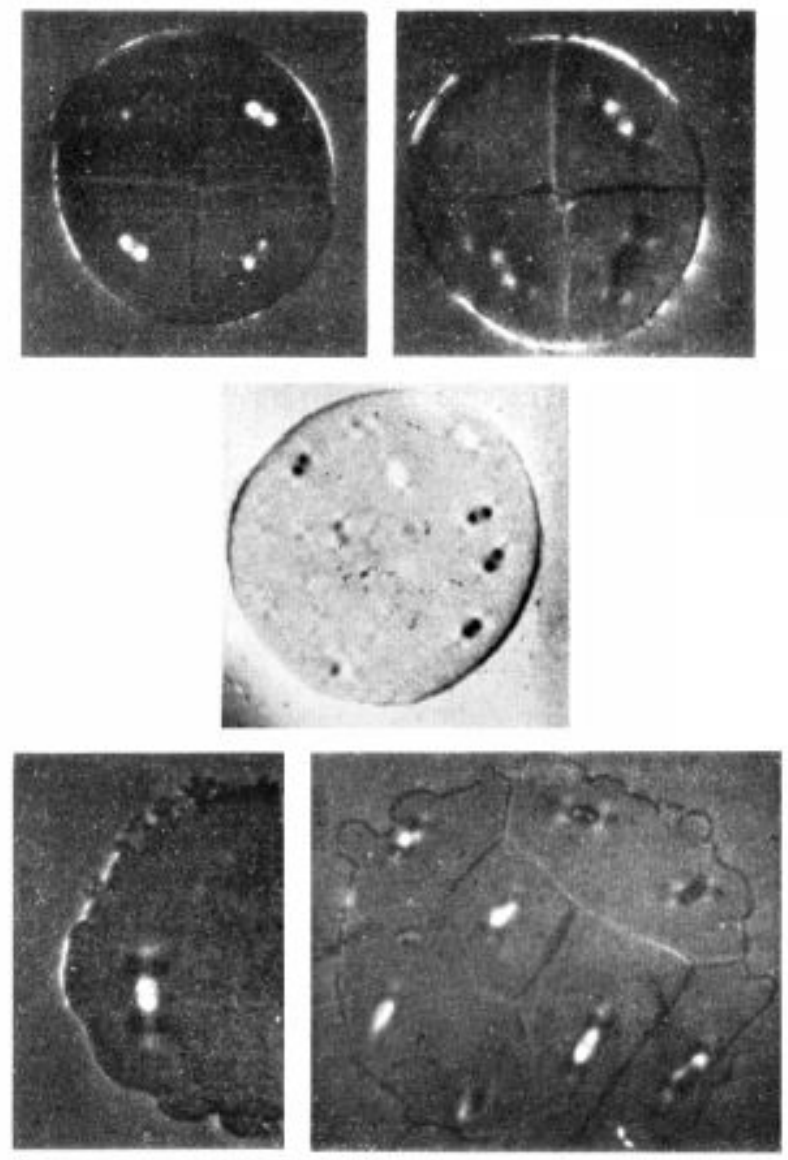
Scope with analyzer attached to bottom of draw tube

Mica Compensator

Calcite prism polarizer

Tea can housing $\mathrm{AH}-4 \mathrm{Hg}$ lamp

Floor

Parts on wood blocks secured by twine on discarded machine-gun base (Misaki, March 1948) 


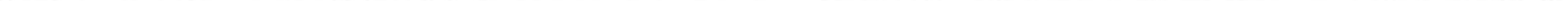



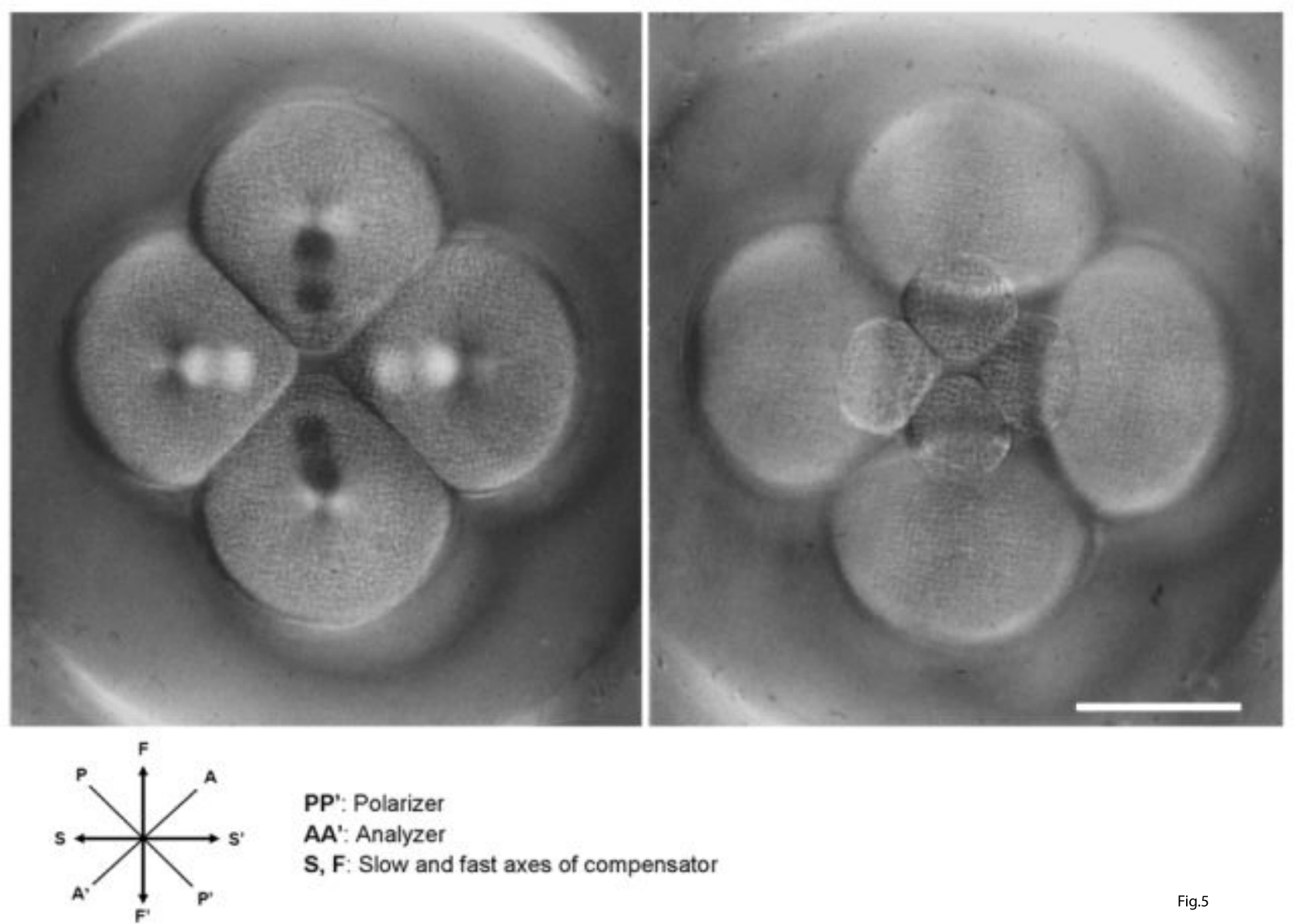

PP': Polarizer

AA': Analyzer

S, F: Slow and fast axes of compensator 


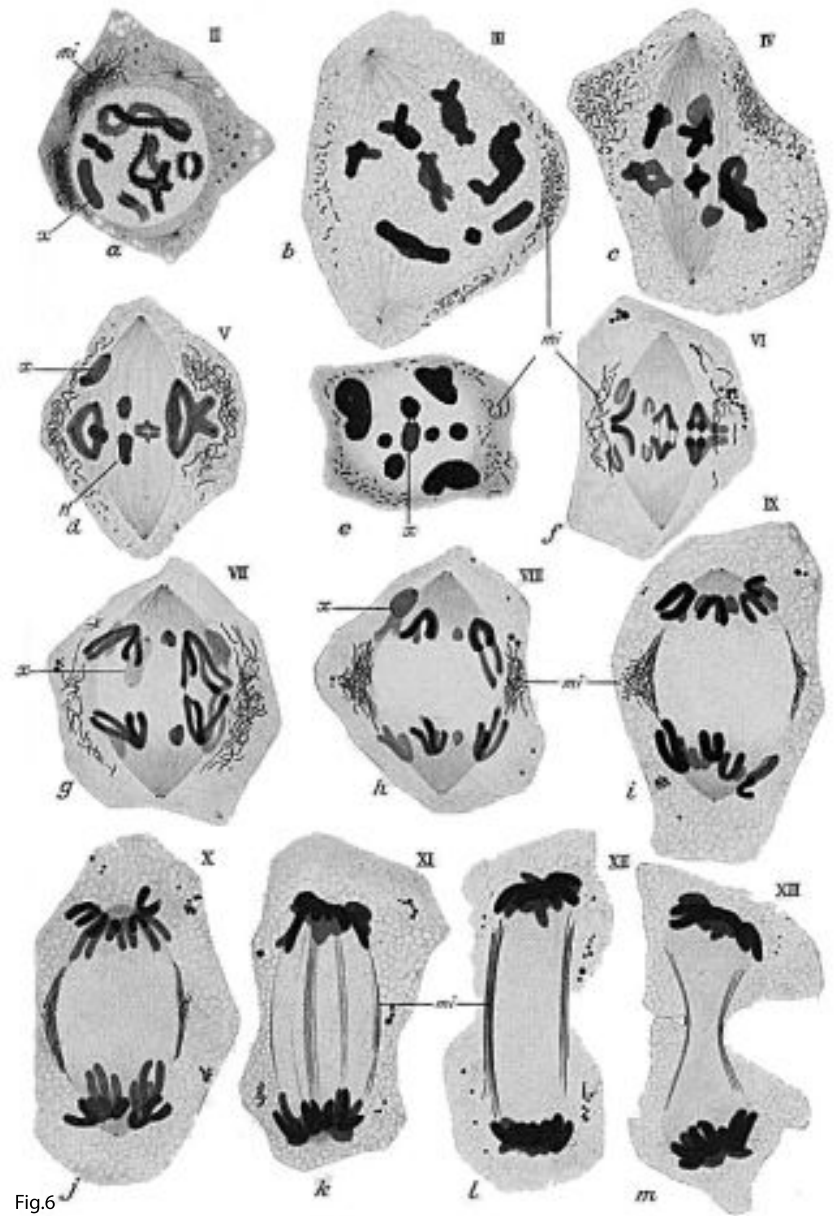




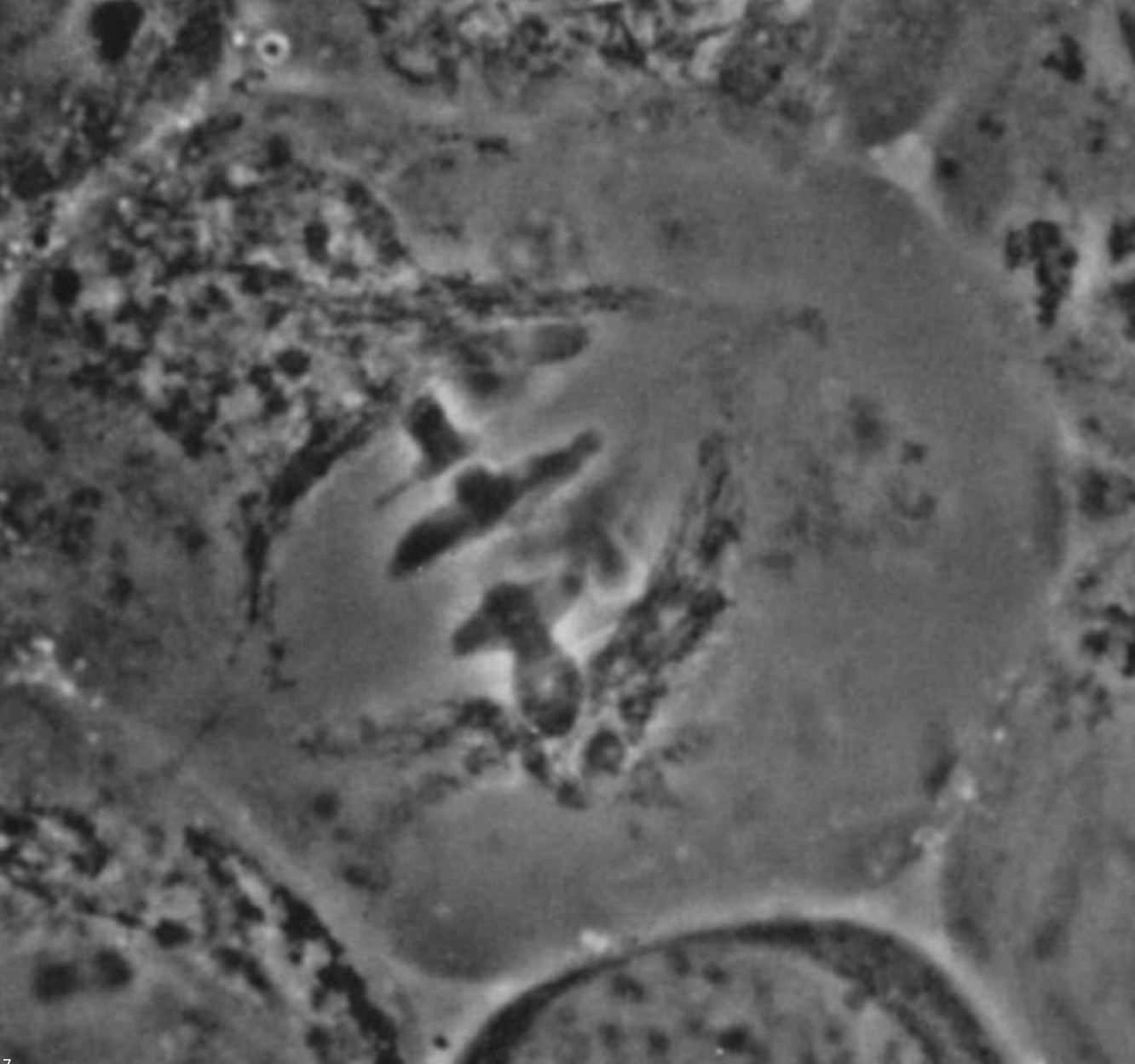



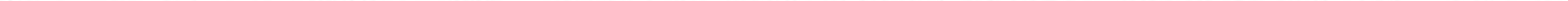

\section{.

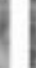

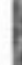 \\ (1)

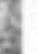
1. - 30 ron .

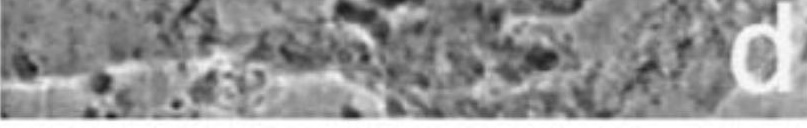



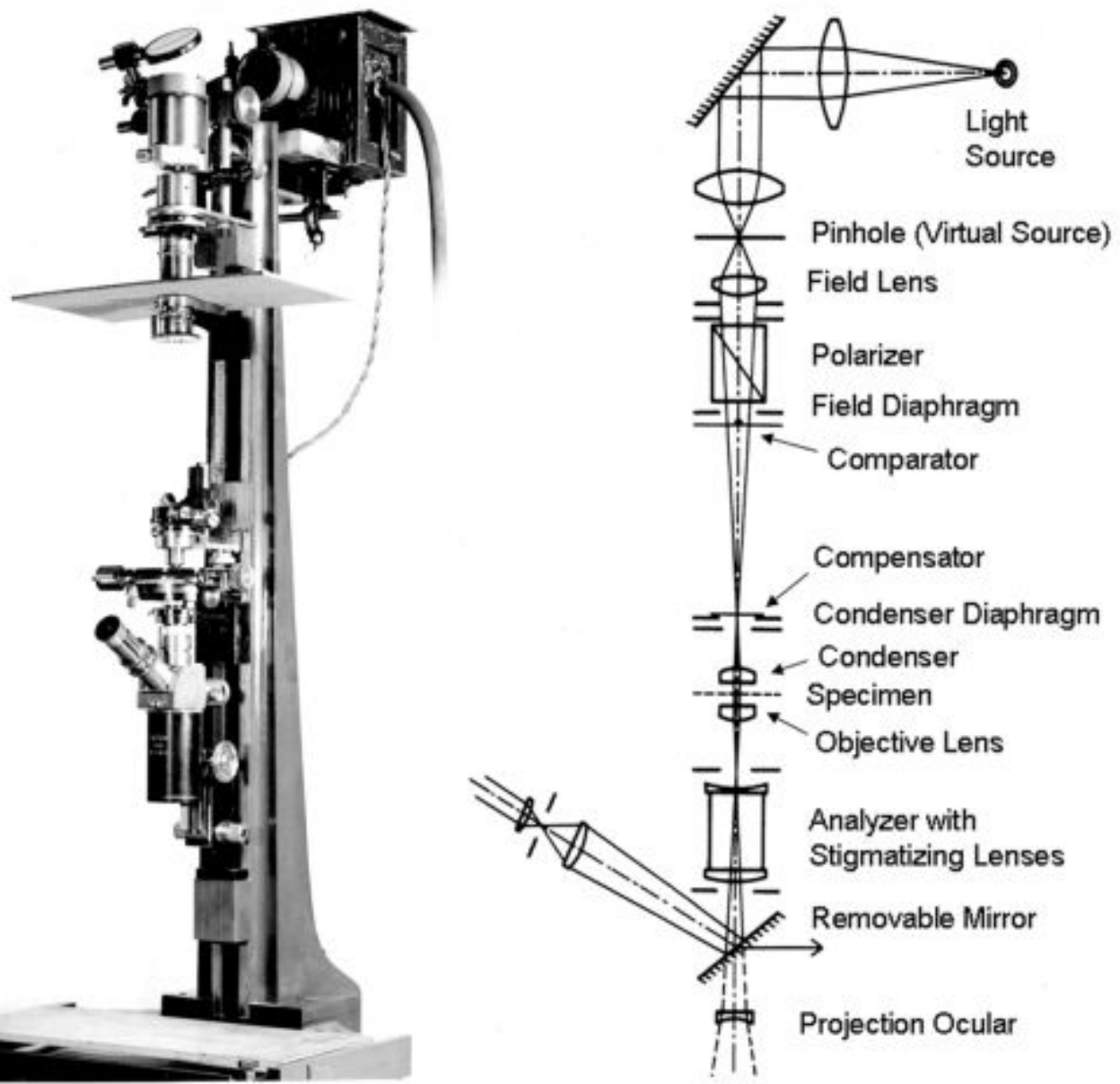

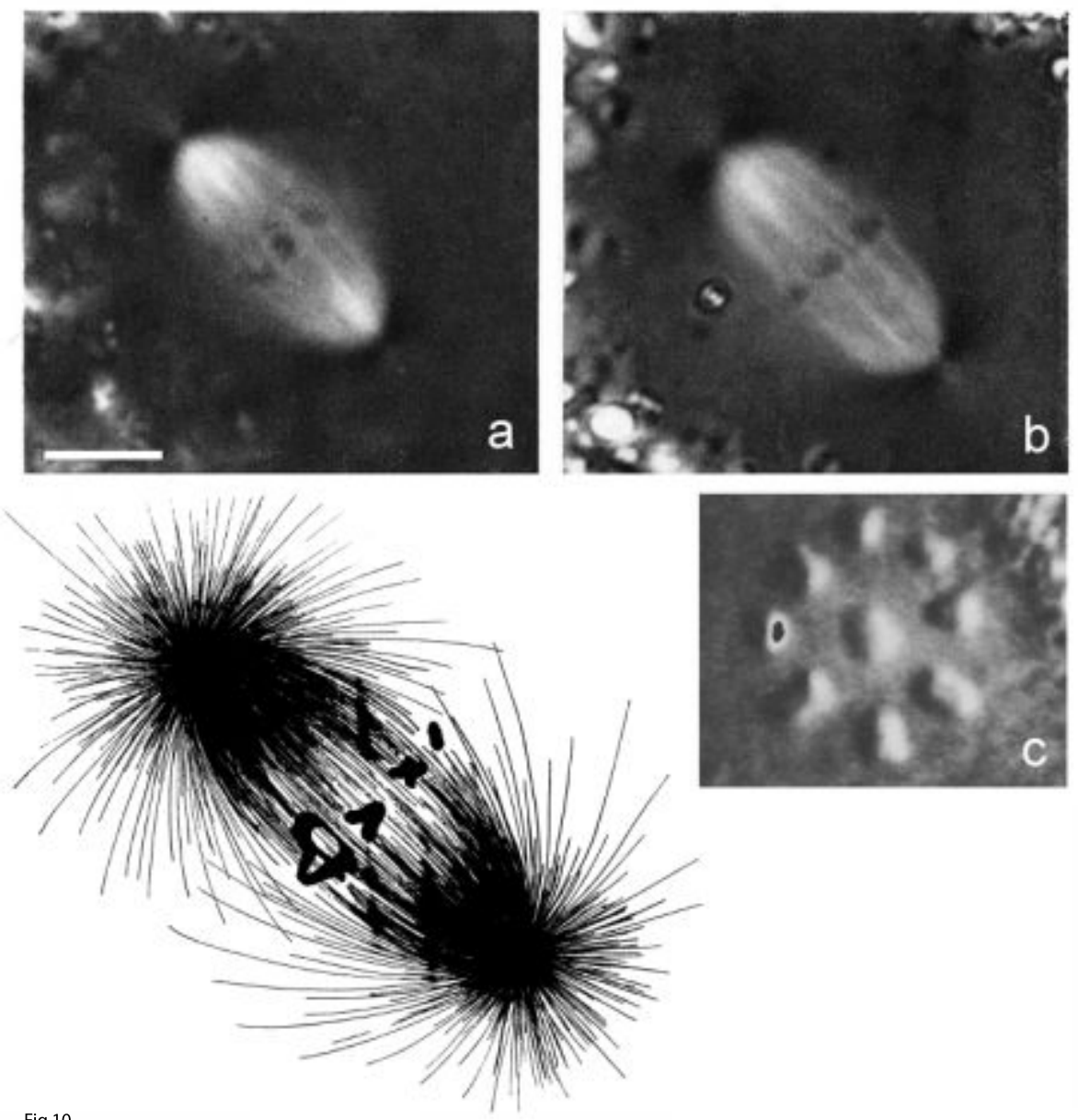

Fig.10 


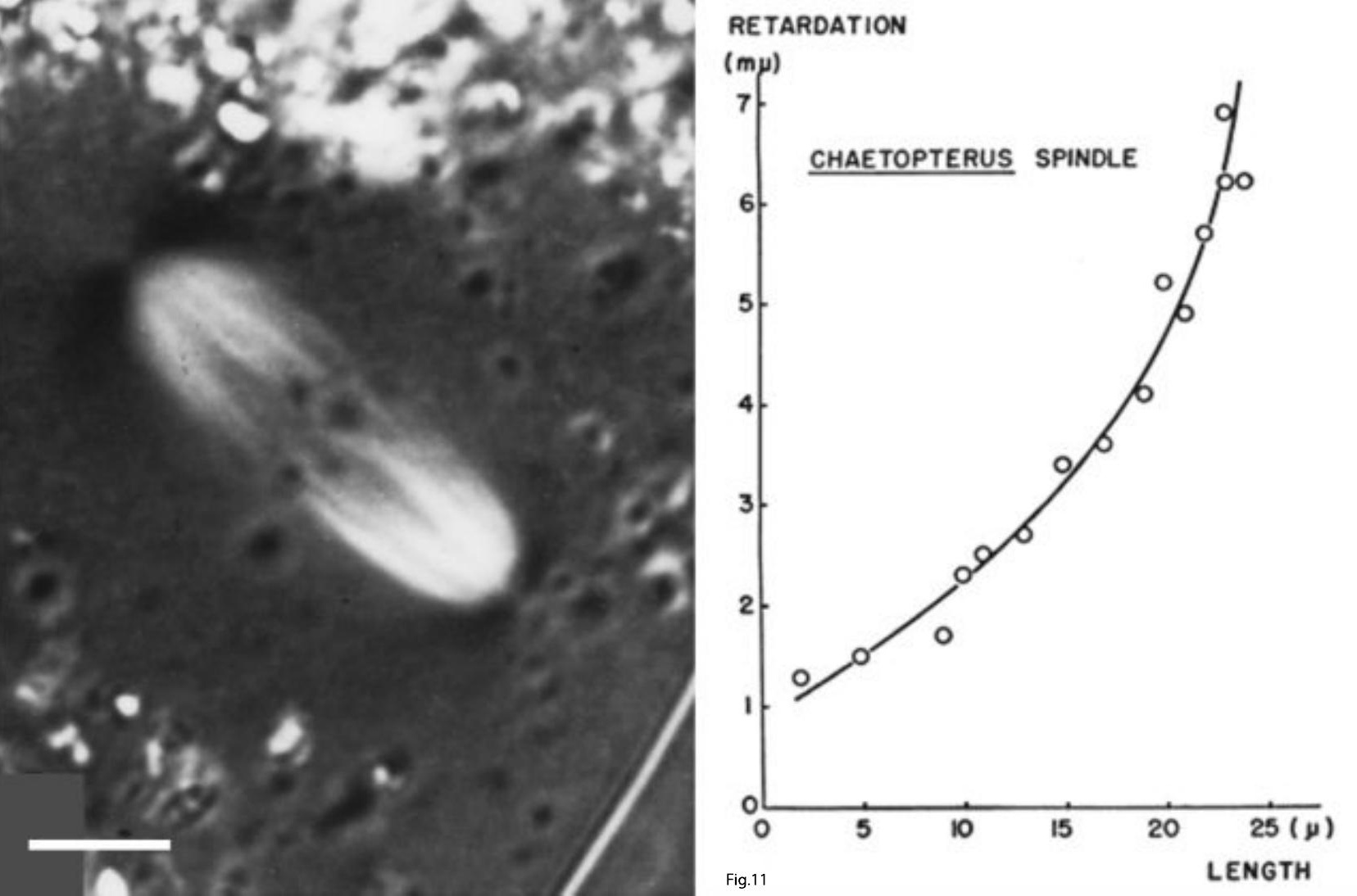




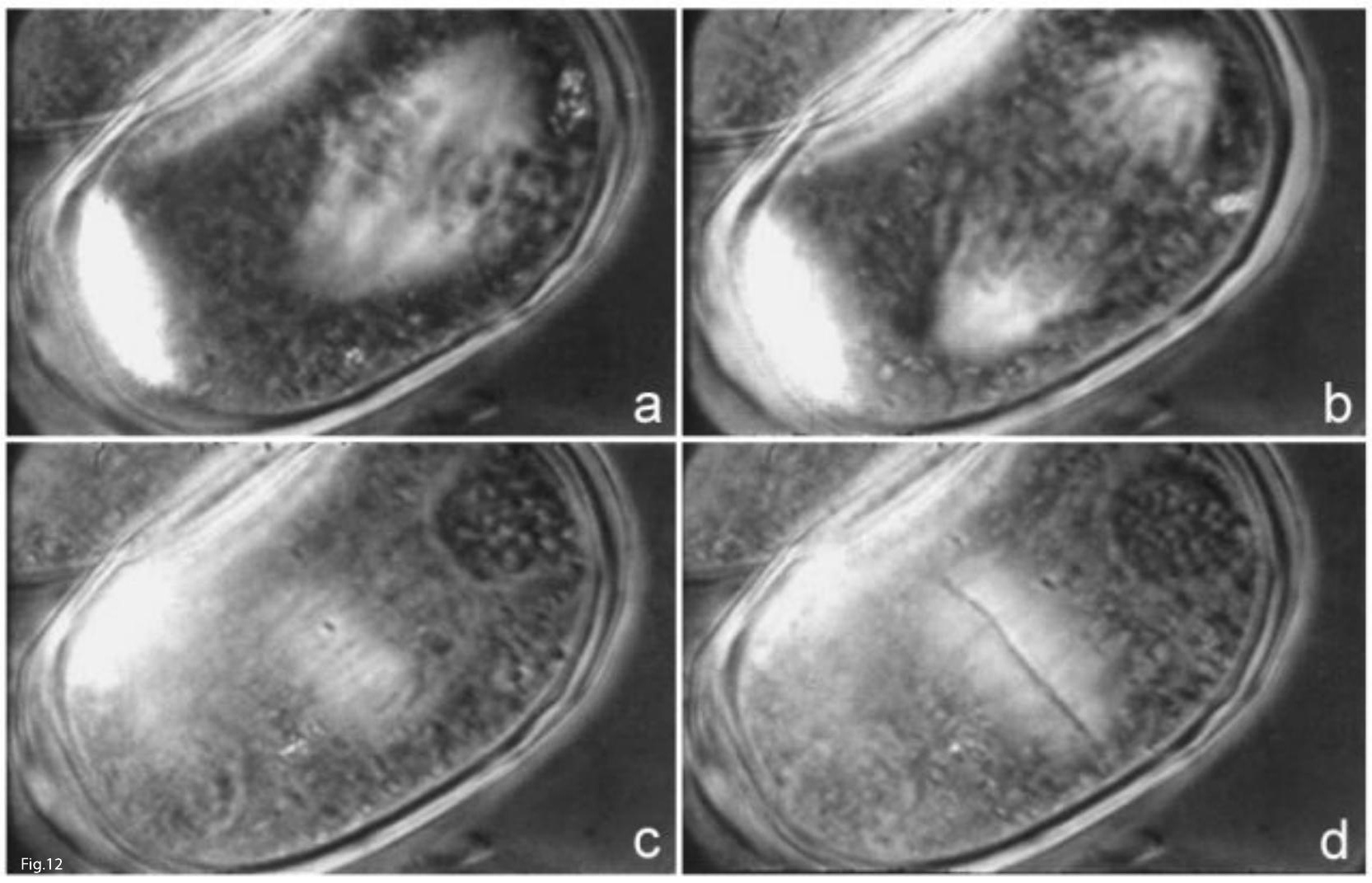




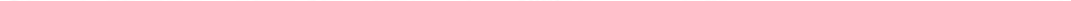




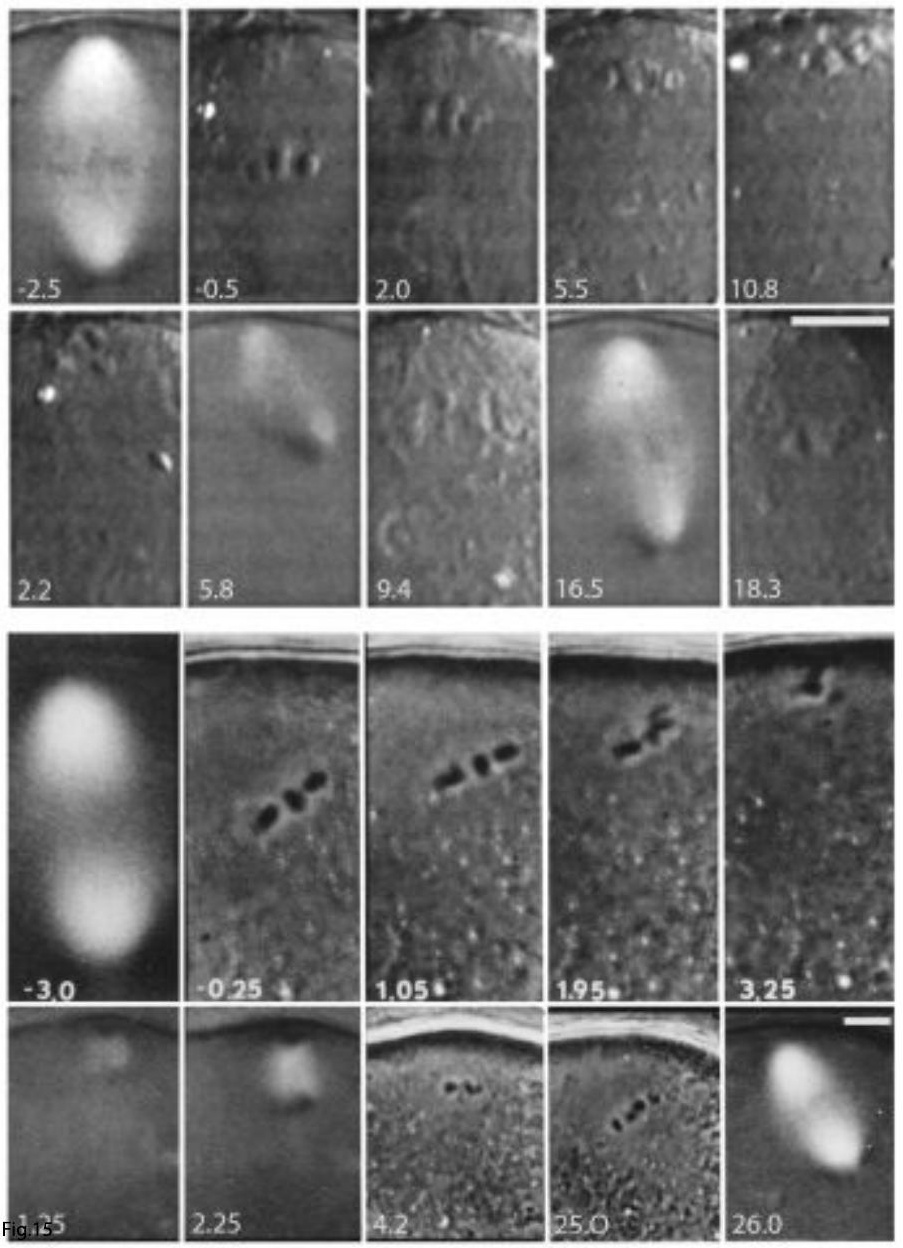




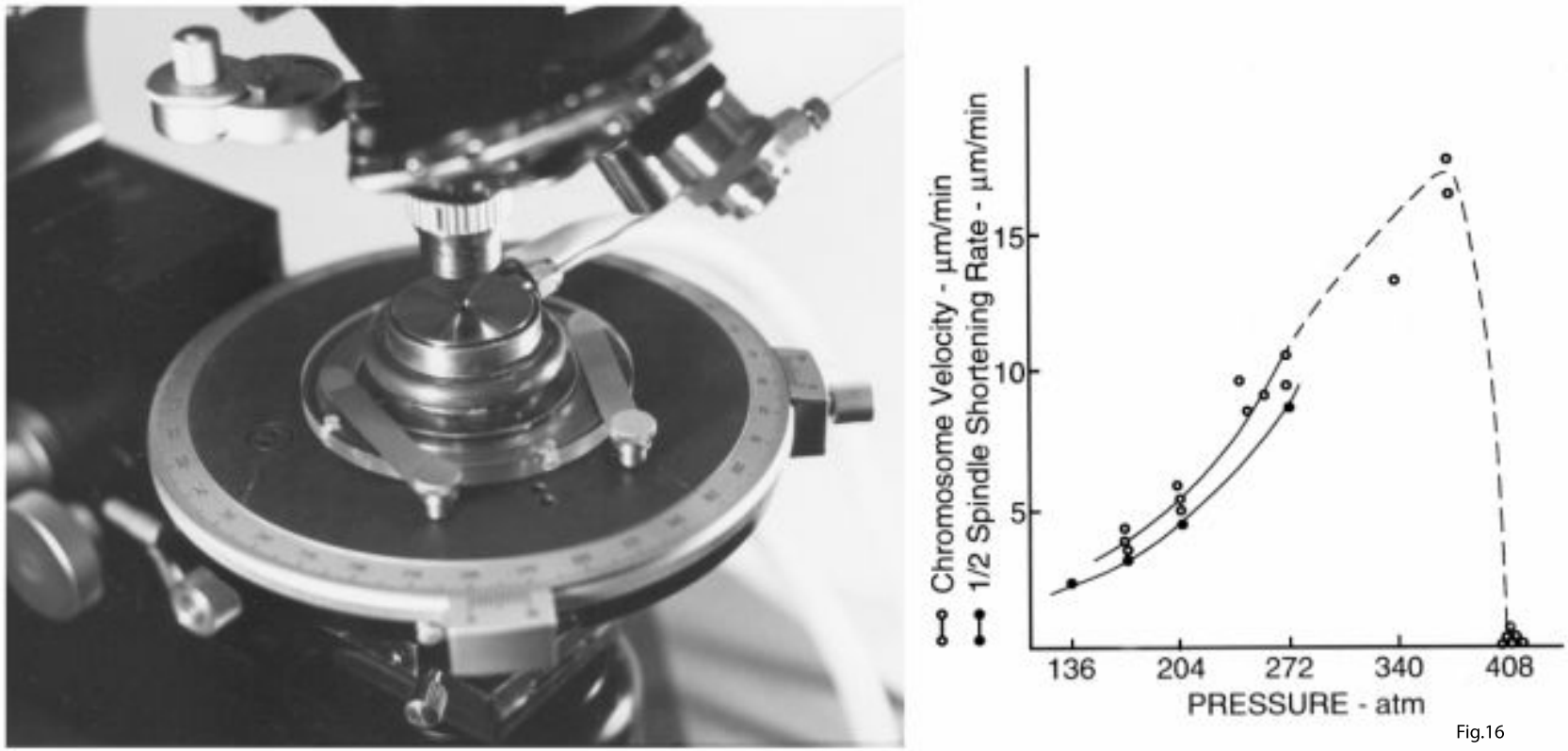





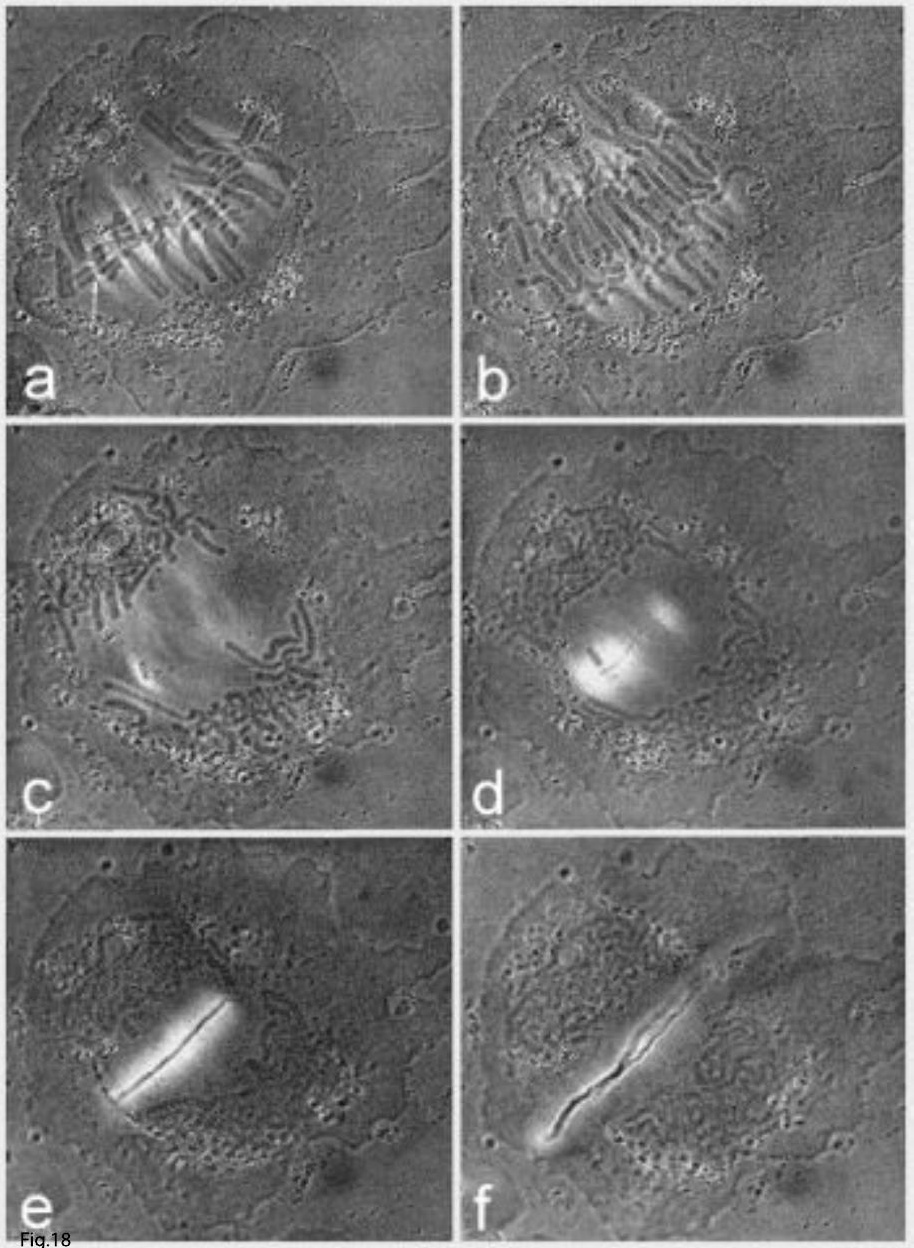




\section{Cold}

Colchicine

Pressure
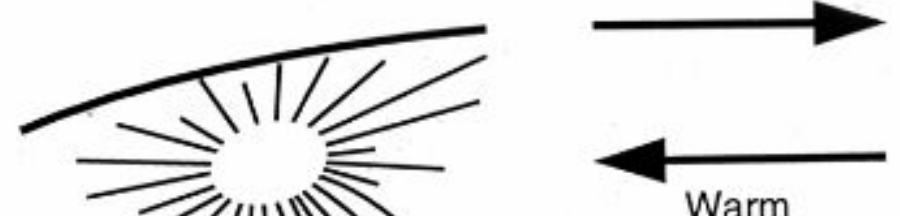

Warm

No Colchicine

$1 \mathrm{Atm}$ 


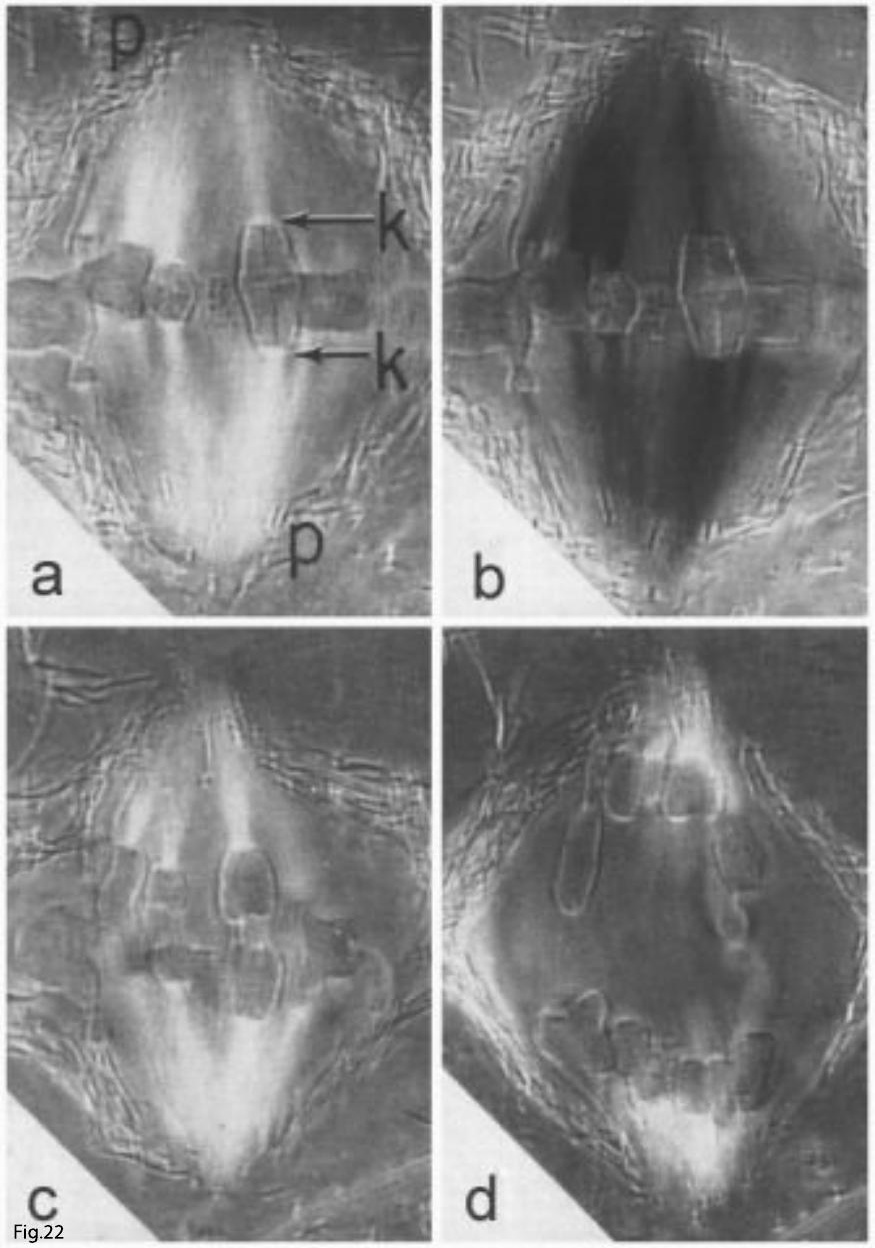




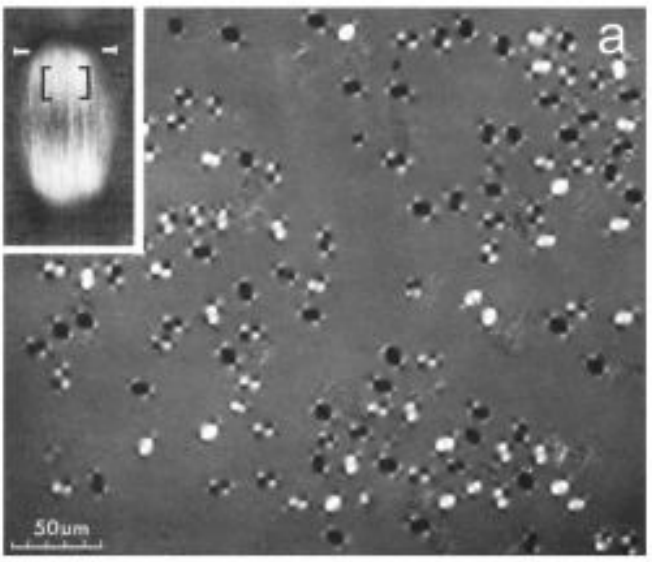

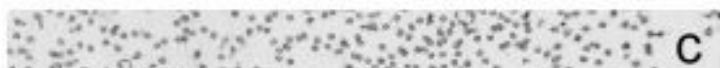

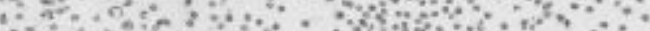
a

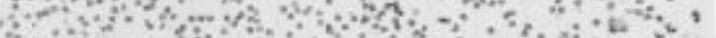

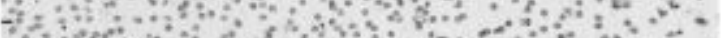
1

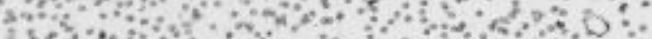

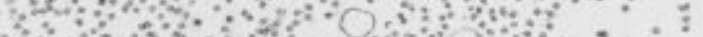

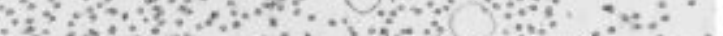

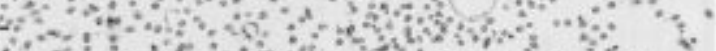

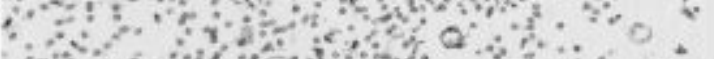

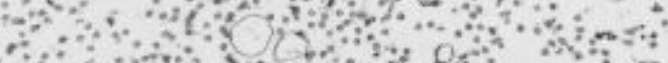

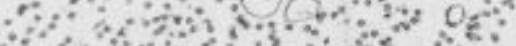

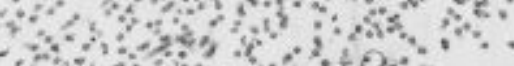

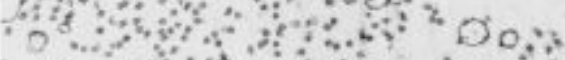

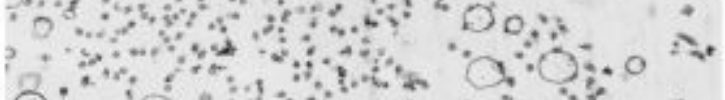

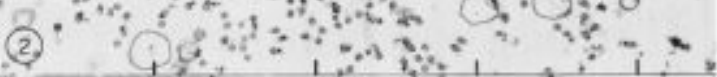

PLOT DF NIENEAIS EOUATION FOA FDRM GI REFRINEENCE DF RDDLETS PQA $: N I=1451$ T I=

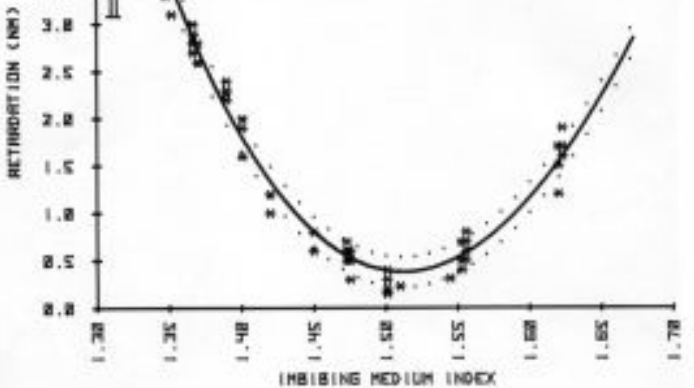

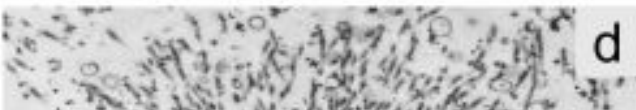

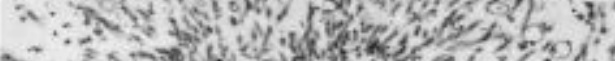

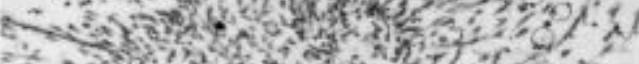

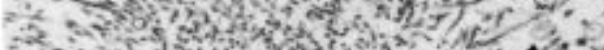

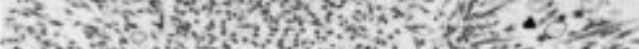

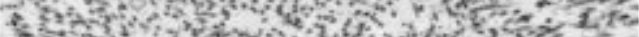

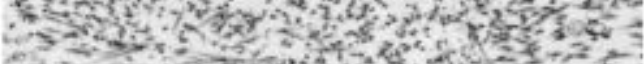

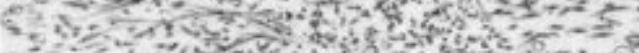

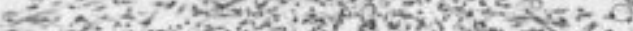

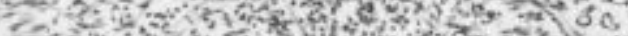

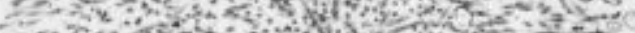

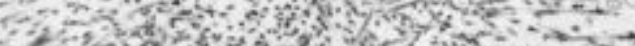

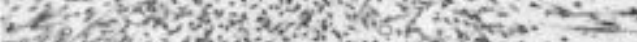

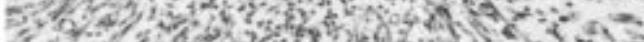

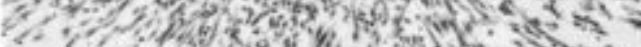

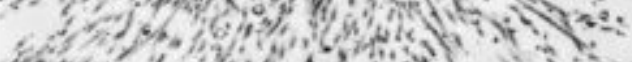

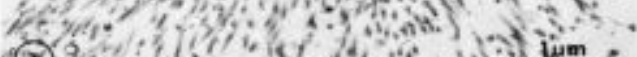

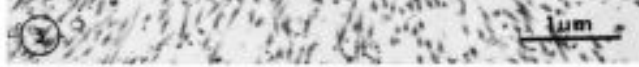

